\title{
Proto Kranz-like leaf traits and cellular ionic regulation are associated with salinity tolerance in a halophytic wild rice
}

\author{
Miing-Tiem Yong ${ }^{1 \dagger}$, Celymar Angela Solis ${ }^{1,2 \dagger}$, Samuel Amatoury ${ }^{1}$, Gothandapani Sellamuthu ${ }^{3}$, Raja Rajakani ${ }^{3}$, \\ Michelle Mak', Gayatri Venkataraman³, Lana Shabala², Meixue Zhou², Oula Ghannoum², Paul Holford', \\ Samsul Huda ${ }^{1}$, Sergey Shabala ${ }^{5,2^{*}}$ and Zhong-Hua Chen ${ }^{1,4^{*}}$
}

\begin{abstract}
Species of wild rice (Oryza spp.) possess a wide range of stress tolerance traits that can be potentially utilized in breeding climate-resilient cultivated rice cultivars (Oryza sativa) thereby aiding global food security. In this study, we conducted a greenhouse trial to evaluate the salinity tolerance of six wild rice species, one cultivated rice cultivar (IR64) and one landrace (Pokkali) using a range of electrophysiological, imaging, and whole-plant physiological techniques. Three wild species (O. latifolia, $\mathrm{O}$. officinalis and $\mathrm{O}$. coarctata) were found to possess superior salinity stress tolerance. The underlying mechanisms, however, were strikingly different. $\mathrm{Na}^{+}$accumulation in leaves of $\mathrm{O}$. latifolia, O. officinalis and O. coarctata were significantly higher than the tolerant landrace, Pokkali. $\mathrm{Na}^{+}$accumulation in mesophyll cells was only observed in O. coarctata, suggesting that $\mathrm{O}$. officinalis and O. latifolia avoid $\mathrm{Na}^{+}$ accumulation in mesophyll by allocating $\mathrm{Na}^{+}$to other parts of the leaf. The finding also suggests that $\mathrm{O}$. coarctata might be able to employ $\mathrm{Na}^{+}$as osmolyte without affecting its growth. Further study of $\mathrm{Na}^{+}$allocation in leaves will be helpful to understand the mechanisms of $\mathrm{Na}^{+}$accumulation in these species. In addition, O. coarctata showed Proto Kranz-like leaf anatomy (enlarged bundle sheath cells and lower numbers of mesophyll cells), and higher expression of $\mathrm{C}_{4}$-related genes (e.g., NADPME, PPDK) and was a clear outlier with respect to salinity tolerance among the studied wild and cultivated Oryza species. The unique phylogenetic relationship of $O$. coarctata with $C_{4}$ grasses suggests the potential of this species for breeding rice with high photosynthetic rate under salinity stress in the future.
\end{abstract}

Keywords: Gas exchange, Gene expression, Ion flux, $\mathrm{Na}^{+}$imaging, Oryza sativa, Oryza coarctata

\section{Introduction}

Salinity tolerance is a polygenetic trait that has evolved multiple times in diverse genera (Bromham et al. 2020) due to various modifications in plant physiological and anatomical traits (Chen and Soltis 2020; Munns et al.

\footnotetext{
*Correspondence: Sergey.shabala@utas.edu.au;

z.chen@westernsydney.edu.au

${ }^{+}$Miing-Tiem Yong and Celymar Angela Solis contributed equally to this work.

${ }^{5}$ International Research Centre for Environmental Membrane Biology, Foshan University, Foshan 528000, China

${ }^{1}$ School of Science, Western Sydney University, Penrith, NSW 2751, Australia

Full list of author information is available at the end of the article
}

2020a; Solis et al. 2020). Phylogenetic analysis shows that salt-tolerant lineages exhibit a 'tippy' pattern (occurring on the tips of the phylogeny rather than internally) (Flowers et al. 2010; Bromham et al. 2020). This may suggest a potential loss or gain of salt-tolerant traits in different species during their evolutionary and ecological adaptation to saline conditions (Bromham et al. 2020; Chen and Soltis 2020; Caperta et al. 2020). Salt tolerance also appears to have evolved more frequently in plants with $\mathrm{C}_{4}$ rather than $\mathrm{C}_{3}$ photosynthesis (Bromham and Bennett 2014).

\section{Springer}

() The Author(s). 2022 Open Access This article is licensed under a Creative Commons Attribution 4.0 International License, which permits use, sharing, adaptation, distribution and reproduction in any medium or format, as long as you give appropriate credit to the original author(s) and the source, provide a link to the Creative Commons licence, and indicate if changes were made. The images or other third party material in this article are included in the article's Creative Commons licence, unless indicated otherwise in a credit line to the material. If material is not included in the article's Creative Commons licence and your intended use is not permitted by statutory regulation or exceeds the permitted use, you will need to obtain permission directly from the copyright holder. To view a copy of this licence, visit http://creativecommons.org/licenses/by/4.0/. 
The genus Oryza (Poales, Poaceae) contains 24 species (Ge et al. 2001), with the Asian rice, O. sativa, and African rice, O. glaberrima, being staple crops for over half of the global population (Grieve et al. 2019). Cultivated rice is highly susceptible to salinity stress, and a yield penalty occurs at low salinity levels with electrical conductivities (EC) of $3 \mathrm{dS} \mathrm{m}^{-1}$ (Munns et al. 2006; Khatun and Flowers 1995; Lutts et al. 1995). In the cultivated rice, $O$. sativa, salt exclusion from roots, retrieval from the shoots, tissue tolerance (achieved by efficient vacuolar $\mathrm{Na}^{+}$compartmentation and cytosolic $\mathrm{K}^{+}$retention), ROS detoxification, and osmotic adjustment are considered to be the main salinity tolerance mechanisms (Malagoli et al. 2008; Nemati et al. 2011; Kavitha et al. 2012; Kobayashi et al. 2017; Lakra et al. 2018; Oda et al. 2018; Liu et al. 2019). Attempts to increase salinity tolerance have mostly focused on traits found in salt-tolerant genotypes such as Pokkali, Nona Bokra and FL468, that have poor reproductive performance resulting in low yields. Salinity tolerance in these lines is mainly achieved by restricting $\mathrm{Na}^{+}$accumulation in aboveground tissues and by maintaining higher $\mathrm{K}^{+}$contents (Lutts et al. 1996b, a; Prusty et al. 2018; Gerona et al. 2019). However, development of salinity tolerant lines using these landraces has produced plants that also have poor reproductive traits (Solis et al. 2020), suggesting a negative trade-off between salt sensitivity and yield.

To date, only limited numbers of highly salttolerant wild Oryza have been reported. One is halophytic O. coarctata (KKLL genome). Previous findings have demonstrated that salt-tolerant wild rice species employ tolerance mechanisms different from $O$. sativa. This suggests that salinity tolerance in the genus Oryza may have been acquired in multiple, independent, and recent events similar to the trait's acquisition in other genera (Bromham et al., 2020). In rice, breeding for salinity tolerance using wild relatives has mostly focused on $O$. rufipogon and $O$. nivara, two species that have the same AA genome as cultivated rice (Ganeshan et al. 2016; Wang et al. 2017c). The glycophytic species, O. officinalis (EE), $O$. latifolia (CCDD), and O. alta (CCDD) were found to have higher leaf $\mathrm{Na}^{+}$accumulation during salinity treatment (Nakamura et al. 2002; Nishizawa et al. 2015; Prusty et al. 2018; Yichie et al. 2018). Halophytic $O$. coarctata has unique morphological and anatomical features such as thick and waxy leaves that contain salt glands and a differentiated rhizome that adapted to high salinity in coastal areas (Sengupta and Majumder 2010; Rajakani et al. 2021). However, ion homeostasis of photosynthetically active mesophyll tissue of $O$. coarctata in response to high salinity remains unclear.

Leaf $\mathrm{Na}^{+}$exclusion and $\mathrm{Na}^{+}$sequestration are two main mechanisms of plants in response to $\mathrm{Na}^{+}$stress (Hanin et al. 2016). Exclusion is mainly mediated by plasma membrane Salt Overly Sensitive1 (SOS1) antiporters that exclude $\mathrm{Na}^{+}$from mesophyll and retrieval into xylem parenchyma cells via High affinity $\mathrm{K}^{+}$Transporter1 (HKT1) transporters (Hamamoto et al. 2015). The former is controlled by the SOS signalling pathway, which is consists of SOS3, SOS2 and SOS1 mediated by $\mathrm{Ca}^{2+}$ and ROS signals (Ji et al. 2013). $\mathrm{Na}^{+}$sequestration mainly carried by $\mathrm{Na}^{+} / \mathrm{H}^{+}$exchanger1 (NHX1) antiporters from the cytosol to the vacuole (Kronzucker and Britto 2011). Sequestered $\mathrm{Na}^{+}$can be used as a 'cheap osmoticum' to increase the salt concentration in vacuoles and thereby enhance water retention in cell when the external concentration of $\mathrm{Na}^{+}$is high. Moreover, transporters involved in $\mathrm{K}^{+}$retention are also important for maintaining high cytosolic $\mathrm{K}^{+} / \mathrm{Na}^{+}$ratios (Shabala and Cuin 2008), such as HAK transporters and KEA transporters (Rodríguez-Rosales et al. 2008; Bassil et al. 2011; Shen et al. 2015; Tsujii et al. 2019). The tonoplast and plasma membrane-based proton pumps, V-PPase, $\mathrm{V}$-ATPase and $\mathrm{H}^{+}$-ATPase, are also important for providing the $\mathrm{H}^{+}$driving force for $\mathrm{Na}^{+}$transport (Queirós et al. 2009; Zhang et al. 1999). However, the functions of these two salt tolerance mechanisms are not fully explored in wild rice species.

$O$. coarctata is found in coastal environments that have daily fluctuations in EC between 20 and $40 \mathrm{dS} \mathrm{m}^{-1}$. $O$. coarctata is the only Oryza species with a welldeveloped, putative, Kranz-like anatomy and has enlarged bundle sheath cells associated with a deep leaf furrow on the adaxial side of the leaf and a pair of longitudinally oriented vascular veins on each leaf ridge (Chatterjee et al. 2016; Rajakani et al. 2019). In $C_{4}$ plants, enlarged bundle sheaths, reduced mesophyll cell/ vascular bundle sheath cell size ratios, and a reduced number of mesophyll cells between vascular system in leaves are fundamental structures for $\mathrm{C}_{4}$ photosynthesis (Hatch 1987). These features in O. coarctata may compensate for the increased distance between the upper mesophyll cells and the main vein due to increased leaf thickness and may contribute to the adaptation to extreme, saline environments. The incorporation of $\mathrm{C}_{4}$ photosynthesis into new rice cultivars is suggested as a potential innovative technology towards another Green Revolution to meet future food demand (von Caemmerer et al. 2012). However, the development of $\mathrm{C}_{4}$ rice has mostly relied on the introduction of genes from $\mathrm{C}_{4}$ grasses (e.g., maize and sorghum) as no $\mathrm{C}_{4}$ Oryza species has been discovered so far (Wang et al. 2016c). A $\mathrm{C}_{4}$ wild Oryza species would be ideal to study 
evolution and function Kranz anatomy, and $\mathrm{C}_{4}$ photosynthesis and would facilitate the development of $\mathrm{C}_{4}$ cultivated rice.

In this study, we evaluated the salinity tolerance of six wild Oryza species, one salt-tolerant landrace and a saltsensitive cultivar of cultivated rice in the greenhouse. We hypothesized that $O$. coarctata is a $\mathrm{C}_{3}-\mathrm{C}_{4}$ intermediate grass that has salt tolerance linked to the evolution of Kranz leaf anatomy and photosynthesis. Our measurements focused on the response to salinity of typical tolerance indicators (e.g., biomass, $\mathrm{Na}^{+} / \mathrm{K}^{+}$ratio), photosynthesis, ion transport [as assessed by microelectrode ion flux estimation (MIFE)], confocal imaging of reactive oxygen species (ROS) and $\mathrm{Na}^{+}$concentrations in mesophyll cells, and expression of genes associated with ion transporters and $\mathrm{C}_{4}$-related proteins. Our data suggest that three wild species, O. latifolia, O. officinalis, and $O$. coarctata, are all highly tolerant of salinity stress; however, this was achieved by employing different mechanisms. All these species accumulated significant amounts of $\mathrm{Na}^{+}$in the shoot. However, $\mathrm{Na}^{+}$accumulation in mesophyll cells was only observed in O. coarctata, while $O$. officinalis and O. latifolia may allocate $\mathrm{Na}^{+}$to other leaf/shoot tissues. It is concluded that the above traits may be used as a potential target for breeding salt-tolerant rice cultivars.

\section{Results}

Although salinity stress had a significant, negative effect on the performance of all plants, a large variation in stress tolerance was observed amongst the various rice lines. The relative values of the growth and physiological parameters of these lines were ranked using the homogenous groups assigned by DMRTs (Supplementary Table S2). According to the ranking, overall performance under saline conditions was (from poorest to greatest) as follows: $O$. longiglumis $<\mathrm{IR} 64<O$. australiensis $<$ O. rufipogon $<$ O. latifolia $=O$. officinalis $<$ Pokkali $<$ O. coarctata.

Significant reductions in biomass due to salinity stress were found in O. longiglumis, IR64, O. australiensis, and O. rufipogon $(P<0.05$; salinity-sensitive lines) (Supplementary Figs. 1) but not for O. latifolia, Pokkali, and $O$. officinalis and O. coarctata (salt-tolerant lines); O. coarctata even showed a small (although non-significant) increase in biomass under salinity treatment. Tiller numbers and plant heights were not significantly affected by salinity treatment in any of the species (Supplementary Figs. S1). In terms of photosynthetic properties, total chlorophyll, net $\mathrm{CO}_{2}$ assimilation rates $(A)$, stomata conductance $\left(g_{s}\right)$, and transpiration rates $(E)$ of salinity stressed plants were significantly (ANOVA, treatment effect, $p<0.001)$ reduced compared to those in the control plants. Significant reductions in the total chlorophyll contents, $\mathrm{CO}_{2}$ assimilation rates $(A)$, stomata conductance $\left(g_{s}\right)$, and transpiration rates $(E)$ were found in sensitive species- $O$. longiglumis (except $g_{s}$ and $E, P>$ 0.05), IR64, and O. rufipogon (Figs. 1). Compared to the other rice species, $O$. coarctata showed unique photosynthetic parameters such as significantly higher $A$ and water use efficiency (WUE) and lower intercellular $\mathrm{CO}_{2}$ concentrations $(\mathrm{Ci})$; these parameters were not affected by the salinity treatment.

\section{Ion transport in leaf mesophyll differ dramatically between $O$. coarctata and other Oryza species}

Steady-state $\mathrm{K}^{+}$fluxes from leaf mesophyll were positive (net $\mathrm{K}^{+}$uptake) in salt-sensitive $O$. australiensis and $O$. longiglumis and both cultivated $O$. sativa genotypes (Fig. 2A). The other species showed a small, net $\mathrm{K}^{+}$effluxes of 0 to $-100 \mathrm{nmol} \mathrm{m}^{-2} \mathrm{~s}^{-1}$ except for $O$. coarctata that had much higher net, initial, $\mathrm{K}^{+}$efflux $(-328 \mathrm{nmol}$ $\left.\mathrm{m}^{-2} \mathrm{~s}^{-1}\right)$. When plants were grown under saline conditions, steady-state mesophyll $\mathrm{K}^{+}$fluxes were drastically shifted towards negative values (net $\mathrm{K}^{+}$loss; Fig. 2B) by 200 to $300 \mathrm{nmol} \mathrm{m}^{-2} \mathrm{~s}^{-1}$ (Fig. 2C). O. coarctata was an exception and showed no statistically significant difference in mesophyll $\mathrm{K}^{+}$fluxes between control- and saltgrown plants. When O. coarctata was omitted from the analysis, a strong positive $\left(r^{2}=0.8\right)$ correlation between salinity-induced shift in mesophyll $\mathrm{K}^{+}$fluxes and relative plant growth under saline conditions was found (Fig. 2C).

Net $\mathrm{Na}^{+}$fluxes were around zero in control-grown plants and slightly negative under saline conditions (Fig. 3A). Salinity-induced shifted in net $\mathrm{Na}^{+}$fluxes were about $-150 \mathrm{nmol} \mathrm{m}^{-2} \mathrm{~s}^{-1}$ (Fig. 3B) and did not correlate with relative plant performance $\left(r^{2}=0.10\right.$; not significant; Fig. 3C).

Steady-state mesophyll $\mathrm{Cl}^{-}$fluxes ranged between -50 and $-200 \mathrm{nmol} \mathrm{m}^{-2} \mathrm{~s}^{-1}$ (net efflux) in control and increased by 2 to 3 -fold under saline conditions (Fig. 4A). Salinity-induced changes in $\mathrm{Cl}^{-}$fluxes were strongest in the salt-sensitive cultivars (Fig. 4B) and correlated positively with plant performance $\left(r^{2}=0.59\right.$; Fig. 4C). Again, O. coarctata was an exception from this finding.

\section{Salt-tolerant Oryza species had higher ROS production} and lower $\mathrm{Na}^{+}$accumulation in leaf and mesophyll cells

In response to salinity stress, all species had a significant reductions in leaf $\mathrm{K}^{+}$contents and increases in leaf $\mathrm{Na}^{+}$ contents (Figs. 5, ANOVA, treatment effect, $p<0.001$ ). The sensitive species had the highest reduction in shoot $\mathrm{K}^{+}$content and increase in shoot $\mathrm{Na}^{+}$(ANOVA, treatment"species effect, $\mathrm{p}<0.001)$. Few salt-tolerant wild rice (mostly species with $\mathrm{C}$ genome) have been reported with higher $\mathrm{Na}^{+}$accumulation in shoots compared to 
the salt-tolerant $O$. sativa lines. This was also observed with our leaf $\mathrm{Na}^{+}$contents. $\mathrm{Na}^{+}$contents (Figs. 5D-F) and $\mathrm{Na}^{+} / \mathrm{K}^{+}$ratios (Figs. $5 \mathrm{G}-\mathrm{I}$ ) in the salt-tolerant wild species (O. latifolia, O. officinalis, and O. coarctata) were all significantly higher than the salt-tolerant cultivated genotype Pokkali. Leaf $\mathrm{Na}^{+} / \mathrm{K}^{+}$ratios in the salinitysensitive $O$. sativa lines were significantly increased after prolonged salinity stress. Although there were small increases in this ratio for the tolerant lines, the increase was only significant (t-test, $P<0.05$ ) for $O$. latifolia (Figs. 5G-H). The leaf $\mathrm{Na}^{+}$(negative; $\mathrm{r}^{2}=0.74, \mathrm{P}<0.05$ ), $\mathrm{K}^{+}$ (positive; $\mathrm{r}^{2}=0.80 ; P<0.01$ ) and $\mathrm{Na}^{+} / \mathrm{K}^{+}$ratios (negative; $\left.\mathrm{r}^{2}=0.74, \mathrm{P}<0.05\right)$ were strongly correlated with relative biomass (Supplementary Table S3).

After six weeks of salinity stress, leaf mesophyll cells accumulated significant amounts of ROS (Figs. 6A-D). The ROS contents in leaf mesophyll cells of most species/cultivars ranged between 13 and 19 (arbitrary) units in control-grown plants with the highest ROS accumulation (26 units) found in IR64 and the lowest (10 units) in O. rufipogon (Fig. 6A). Surprisingly, the salinity tolerant species showed higher ROS accumulation in mesophyll after the salinity stress (Fig. 6B). The analysis indicated that ROS accumulation was significantly correlated to the following salinity tolerance indicators: biomass (positive, $\mathrm{r}^{2}=0.66, \mathrm{P}<0.05$ ), $\mathrm{Na}^{+} / \mathrm{K}^{+}$ratio (negative, $\mathrm{r}^{2}=0.75$, $\mathrm{P}<0.05$ ), mesophyll $\mathrm{Na}^{+}$fluorescence (negative, $\mathrm{r}^{2}=$ $0.56, \mathrm{P}<0.05$ ) and net $\mathrm{Cl}^{-}$flux (positive, $\mathrm{r}^{2}=0.79, \mathrm{P}<$ 0.01 ). O. coarctata produced higher ROS concentrations in mesophyll cells and maintained the largest relative biomass in response to salinity treatment (Fig. 6B).

To further confirm whether the $\mathrm{Na}^{+}$was stored in the mesophyll cells of salt-tolerant wild rice species, $\mathrm{Na}^{+}$accumulation in mesophyll cells was evaluated using confocal imaging. The imaging analysis showed a similar trend to that found in leaf $\mathrm{Na}^{+}$contents with mesophyll $\mathrm{Na}^{+}$fluorescence decreasing along with the increase of salt tolerance in those rice species (Figs. 6E-H). The mesophyll $\mathrm{Na}^{+}$fluorescence was moderately correlated to the leaf $\mathrm{Na}^{+}$content (positive, $\mathrm{r}^{2}=0.65, \mathrm{P}<0.05$ ) (Supplementary Table S3) and highly correlated to biomass (negative, $\mathrm{r}^{2}=$ 0.81, $\mathrm{P}<0.01$ ) (Fig. 6G). However, among the tolerant group, only $O$. coarctata had significantly higher mesophyll $\mathrm{Na}^{+}$accumulation. No difference was found between O. latifolia, O. officinalis, and Pokkali.

\section{Salinity stress-induced expression of ion transporter genes reveals stronger ion homeostasis ability in salinity tolerant Oryza species}

We then evaluated the expression of ten salinity tolerance-related genes of two tolerant wild species $(O$. latifolia, O. coarctata), and salt-tolerant (Pokkali) and salt-sensitive (IR64) lines of cultivated rice. sativa. The selected genes included $\mathrm{Na}^{+}$transporters (NHX1, SOS1,
HKT1;4), $\mathrm{K}^{+}$transporters (high affinity potassium transporters [HAK1], HAK5), proton pumps (plasma membrane $H^{+}$-ATPase [AHA1], V-type $H^{+}$ATPase subunit $C$ [VHA-C], and vacuolar PPase [VPPase]), and $\mathrm{Ca}^{2+}$ signaling proteins (SOS2, SOS3). Two-way ANOVA sindicated a significant difference of expression of each gene between species in response to the prolonged salinity treatment (Two-way ANOVA, main effects and species $\times$ treatment effects all $<0.001)$. Expression of the SOS signaling genesSOS2and SOS3, were upregulated in all species except SOS3 expression in salt-sensitive IR64 (Figs. 7A-B). Relative to the control, $\mathrm{Na}^{+}$and $\mathrm{K}^{+}$transporter and proton pump genes were mostly upregulated in the salinity-tolerant wild rice species, O. coarctata, O. latifolia, and the cultivated rice, Pokkali (Figs. 7C-E). OlSOS1 was the only transporter gene downregulated in the salt-tolerant species. The salt-sensitive IR64 had the highest numbers of genes (OsNHX1, OsHKT1;4 \& OsVPPase) downregulated in response to prolonged salinity treatment (Fig. 7K).

Expression of the vacuolar $\mathrm{Na}^{+}$compartmentationrelated transporter, $N H X 1$, was significantly higher in both wild salt-tolerant species (Fig. 7K). On the other hand, the $\mathrm{Na}^{+}$exclusion-related transporter, SOS1, was significantly higher in salt-tolerant $O$. sativa. Correspondingly, the expression of the tonoplast proto pumps, $V H A-C$ and VPPase (only O. coarctata significantly upregulated), was also higher in the wild tolerant species. This finding supported the importance of $\mathrm{Na}^{+}$compartmentation in both wild species, which had shown higher leaf $\mathrm{Na}^{+}$ content and mesophyll $\mathrm{Na}^{+}$compared to the salt-tolerant cultivated rice Pokkali. $\mathrm{Na}^{+}$accumulation in $O$. coarctata's mesophyll was further evaluated in response to direct 50 $\mathrm{mM}$ and $100 \mathrm{mM} \mathrm{NaCl}$ treatments on exposed mesophyll tissue with the epidermal layer removed for $2 \mathrm{~h}$ and in response to 1 week of $100 \mathrm{mM} \mathrm{NaCl}$ hydroponic solution (Supplementary Fig. 2). Consistently, the results showed significant $\mathrm{Na}^{+}$accumulation in the vacuole based on the area and shape of the $\mathrm{Na}^{+}$fluorescence in the cell. The $\mathrm{Na}^{+}$ fluorescence in the mesophyll cell chloroplasts in response to 1 week of $100 \mathrm{mM} \mathrm{NaCl}$ hydroponic solution was surprisingly low compared to the control. The increase in vacuole $\mathrm{Na}^{+}$fluorescence of mesophyll cells with $100 \mathrm{mM}$ $\mathrm{NaCl}$ treatment was 5 times higher than mesophyll with 50 $\mathrm{mM} \mathrm{NaCl}$ treatment. The result suggested that $\mathrm{Na}^{+}$compartmentation is the main strategy of salinity defense in mesophyll cells.

$\mathrm{K}^{+}$inward transporters, HAK1 \& HAK5, were overall upregulated in all species. The expressions were significantly higher in O. coarctata and Pokkali. The foldchange of HAK1 expression was higher than the foldchange of HAK5 in all tolerant species. The fold-change $H A K 1$ was correlated to the leaf $\mathrm{K}^{+}$content (Figs. 5A-C) and biomass (Supplementary Fig. 1), which is highest in O.coarctata, followed by Pokkali, O. latifolia then IR64. 
O. coarctata has a proto Kranz-like anatomy, higher photosynthetic rate, and highly expressed $\mathrm{C}_{4}$ photosynthesis-related genes

$O$. coarctata showed significant photosynthetic capacity in the control and salinity stress in the greenhouse trial (Fig. 1). To evaluate whether $O$. coarctata is a $\mathrm{C}_{4}$ or a $\mathrm{C}_{3}-\mathrm{C}_{4}$ intermediate species, we first constructed a phylogenic tree of a $\mathrm{C}_{4}$-related gene, phosphoenolpyruvate carboxylase (PEPC), for a group of $\mathrm{C}_{3}$ and $\mathrm{C}_{4}$ plants. The phylogeny showed that this gene in $O$. coarctata is phylogenetically closer to those in $\mathrm{C}_{4}$ grasses such as Setaria, maize, and Sorghum compared to other $\mathrm{C}_{3}$ species in the Oryza genus (Fig. 8A).

Overall, $O$. coarctata had significantly $(P<0.01)$ higher total chlorophyll contents, $\mathrm{CO}_{2}$ assimilation rates $(A)$, WUEs, and significantly lower intracellular $\mathrm{CO}_{2}$ concentrations $\left(C_{i}\right)$ compared to the six other Oryza species (Figs. 8B-E). The $\mathrm{A} / \mathrm{Ci}$ curves indicate that $\mathrm{O}$. coarctata was highly responsive to increasing $\mathrm{CO}_{2}$ concentration with $\mathrm{CO}_{2}$ compensation points at $64.5 \mu \mathrm{mol} \mathrm{CO}_{2} \mathrm{~m}^{-2}$ $\mathrm{s}^{-1}$ (3-parameter exponential curve) (Fig. 8F) and $50.4 \mu \mathrm{mol} \mathrm{CO} \mathrm{CO}^{-2} \mathrm{~s}^{-1}$ with a linear fitting of the first 6 points. The photosynthetic characteristics showed the $O$. coarctata may not be a $\mathrm{C}_{4}$ rice.

Leaf anatomy was investigated to confirm if $O$. coarctata possesses proto-Kranz or Kranz anatomy. Under transmission electron microscopy (TEM), plasmodesmata connections between mesophyll and vascular bundle sheath cells were observed (Fig. 8G). The crosssections of $O$. coarctata leaves showed larger vascular bundle sheath cells relative to mesophyll cells, higher numbers of chloroplasts in the vascular bundles, and lower numbers of mesophyll cells between veins. The leaves have distinct adaxial surfaces that have a high density of ridges and furrows (Fig. 8H). Each ridge contains a vascular bundle system, and salt glands for salt exclusion are found on the surface of the furrows. The number of mesophyll cells between each adjacent vascular vein is significantly lower in $O$. coarctata than reported in O. sativa (Chatterjee et al. 2016). Confocal imaging analysis showed a strong $\mathrm{Na}^{+}$signal in the epidermal layer, salt glands, leaf veins, and mesophyll cells (Fig. 8I).

Further, we compared the expression of five $\mathrm{C}_{4}$ photosynthesis-related genes in O. coarctata, IR64, and Pokkali in the control and salinity treatments (Fig. 9). The results indicate that expression of these genes was significantly higher (up to 800-fold for ribulose-bisphosphate carboxylase $[R B C L]$ ) in both control and salinity stressed $O$. coarctata as compared to those in O. sativa. PEPC was the only gene upregulated in $O$. coarctata after the salinity stress while pyruvate phosphate dikinase (PPDK), RBCL, and ribulose-1,5-bisphosphate carboxylase/oxygenase small subunit (RBCS) were significantly downregulated after salinity stress.

\section{Discussion}

More than 10,000 years ago, ancient humans began to consume grains of $O$. rufipogon that grew in the marshes throughout Asia (Sweeney and McCouch 2007). Continuous domestication for desirable traits has slowly caused $O$. rufipogon to evolve into $O$. sativa, a staple crop for billions of people worldwide (Kovach et al. 2007; Sweeney and McCouch 2007). However, after almost 8000 years of cultivation, O. sativa is estimated to only have conserved $20 \%$ of the genetic diversity of wild Oryza (Zong et al. 2007; Palmgren et al. 2015). This narrow genetic diversity is the major constraint on breeding salinity-tolerant rice lines (Waziri et al. 2016; Chen et al. 2020). Thus, investigating gene expression, ion homeostasis, $\mathrm{Na}^{+}$transport between the vascular system and mesophyll tissue in salt-tolerant, wild rice species may enable the identification of new mechanisms that contribute to salt tolerance.

\section{Salt-tolerant wild rice exhibits distinct leaf tissue tolerance to $\mathrm{Na}^{+}$and $\mathrm{K}^{+}$transport compared to 0 . sativa} Salt-tolerant $O$. sativa generally employs $\mathrm{Na}^{+}$exclusion to avoid high $\mathrm{Na}^{+}$accumulation in aboveground tissues. This trait likely results from artificial selection for $\mathrm{Na}^{+}$ exclusion and may account for the poor tissue tolerance to $\mathrm{Na}^{+}$in this rice species (Lutts et al. 1996b, a; Prusty et al. 2018; Gerona et al. 2019). In this study, we evaluated the performance of six wild Oryza species with two lines of cultivated rice after prolonged stress at a moder-

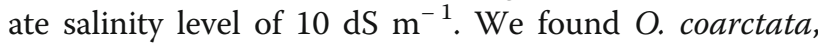
$O$. officinalis, and O. latifolia were highly tolerant of salinity stress. However, only the halophytic O. coarctata showed high $\mathrm{Na}^{+}$accumulation in mesophyll cells when grown under salt stress among salt-tolerant species (Figs. 6), suggesting that the other salt-tolerant wild rice species, O. officinalis, and O. latifolia, avoid $\mathrm{Na}^{+}$accumulation in mesophyll cells.

SOS2 and SOS3 were first identified as key components of the salt overly sensitive pathway to exclude $\mathrm{Na}^{+}$ by activating SOS1 (Ji et al. 2013). Other than SOS1, the $\mathrm{Ca}^{2+}$-activated SOS2/SOS3 complex was also reported to activate/upregulate tonoplast $\mathrm{Ca}^{2+}$ exchangers (CAXs), the internal membrane $\mathrm{Na}^{+}$antiporters, NHX1, NHX2 and NHX4, and the plasma membrane and tonoplast proton pumps,- AHA, V-ATPase, and VPPase (Huertas et al. 2012; Che-Othman et al. 2017; Yang et al. 2019). Expression of these transporter genes (SOS1, NHX1, AHA, VHA-C, and VPPase) was upregulated in the halophytic O. coarctata and mostly upregulated in salt-tolerant Pokkali and O. latifolia. SOS1, HKT1;4, and NHX1 are important $\mathrm{Na}^{+}$transporters responsible for 


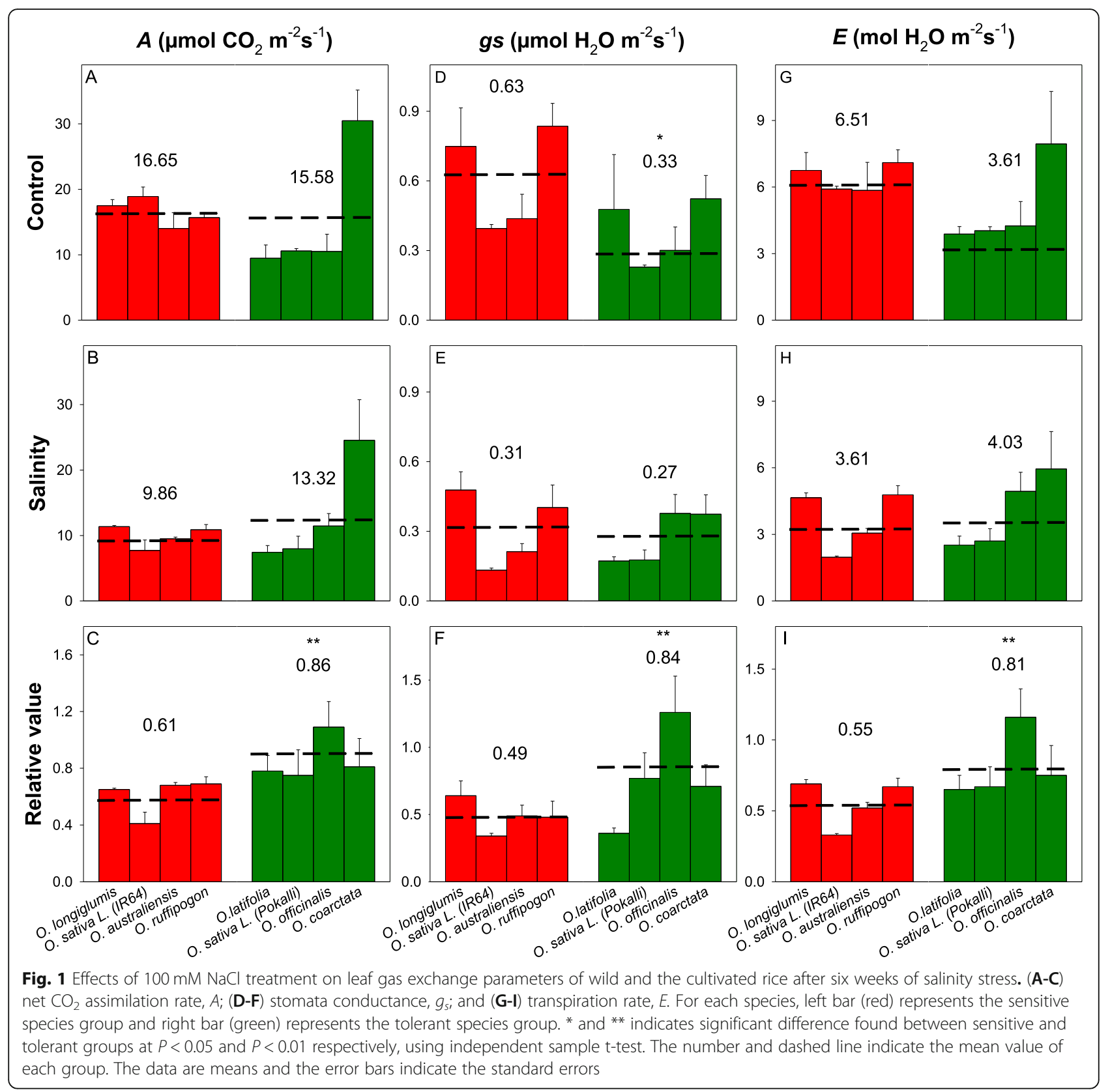

$\mathrm{Na}^{+}$exclusion, compartmentation, and retrieval (Wu et al. 2018). The expression of SOS1 in O. coarctata and $O$. latifolia was consistently low and was not affected by six weeks of salt treatment (Figs. $7 \mathrm{C}, \mathrm{K}$ ). Leaf $\mathrm{Na}^{+}$contents in both species were relatively higher than Pokkali (Figs. 5D-F), suggesting that $\mathrm{Na}^{+}$exclusion may not be a main defense mechanism for salt tolerance in mesophyll cells of these wild rice species. In addition, O. coarctata and O. latifolia had significantly higher NHX1 expression after salinity stress compared to the control and the two cultivated rice lines (Figs. 7D, K). O. coarctata's mesophyll showed a preference to compartmentalise
$\mathrm{Na}^{+}$in the vacuole and regulate apoplastic $\mathrm{Na}^{+}$after the salinity treatment (Supplementary Figs. 2), indicating a key role for NHX1 and HKT1;4 in the leaf salt tolerance of $O$. coarctata. O. latifolia is a member of $O$. officinalis complex, which is well known for its resistance to various biotic and abiotic stresses (Shenton et al. 2020). In this study, mesophyll $\mathrm{Na}^{+}$in O. latifolia was surprisingly low. Given the high leaf $\mathrm{Na}^{+}$content found in O. latifolia, higher relative mesophyll $\mathrm{Na}^{+}$fluorescence was expected compared to Pokkali. $\mathrm{Na}^{+}$homeostasis strategies in leaves of salt-tolerant $O$. latifolia require further investigation. 


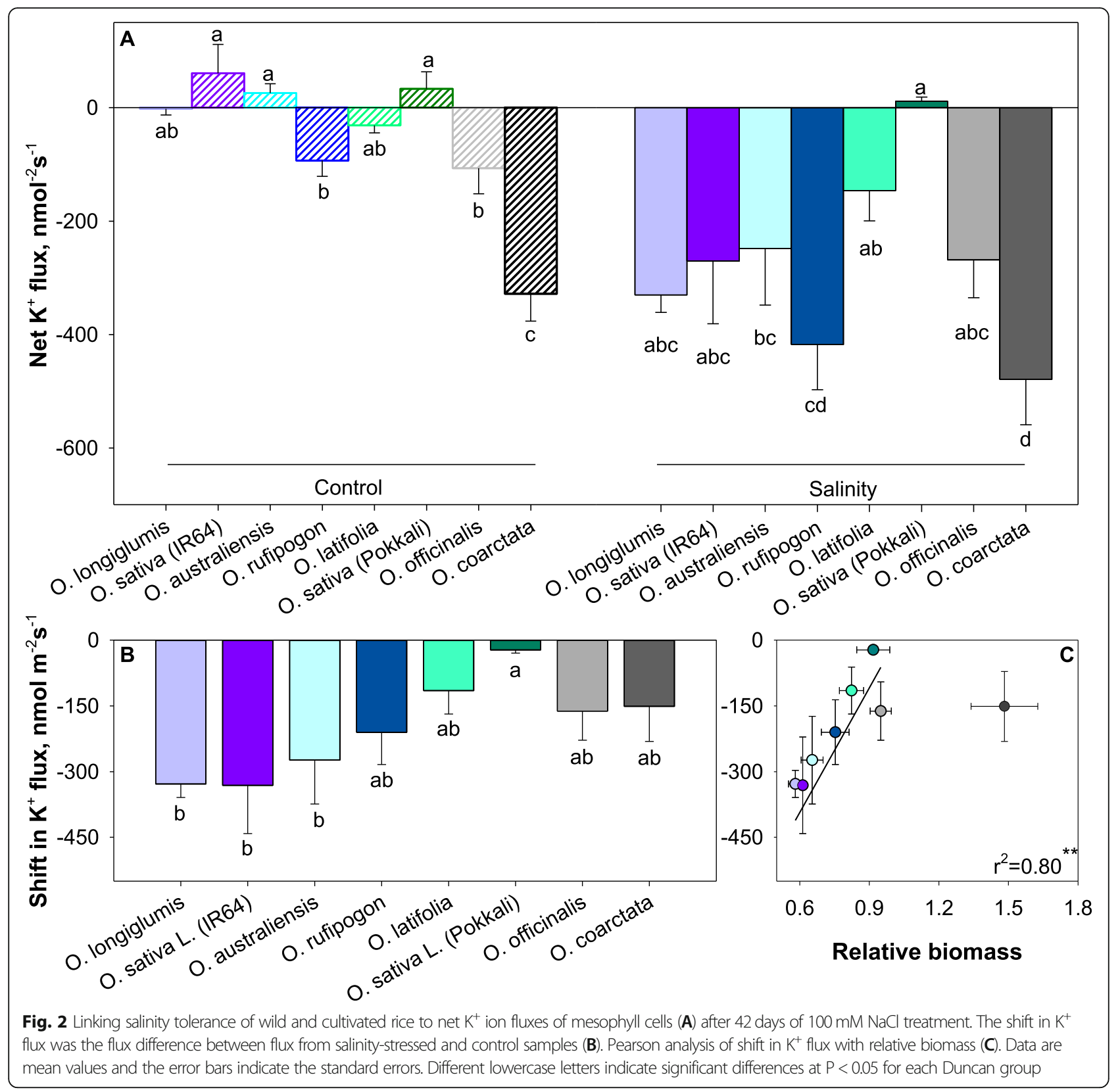

We previously reported a significant, positive correlation between net $\mathrm{K}^{+}$flux and salinity tolerance in $O$. sativa (Yong et al. 2020). Here, except for O. coarctata, we extended this finding to wild Oryza species (Figs. 2). Our results show a significant, strong, and positive correlation between net $\mathrm{K}^{+}$flux and biomass (Fig. 2E). In addition, net $\mathrm{K}^{+}$flux was also significantly and positively correlated with mesophyll $\mathrm{Na}^{+}$, leaf $\mathrm{Na}^{+}$contents, and leaf $\mathrm{Na}^{+} / \mathrm{K}^{+}$ratios (Supplementary Table S3). $\mathrm{K}^{+}$is the macronutrient responsible for the coordination of more than 50 enzymes in plants (Shabala and Cuin 2008). Stress-induced $\mathrm{K}^{+}$leakage from the tissue was reported in plants due to salinity (Liu et al. 2017a), hypoxia
(Wang et al. 2017a), drought (Mak et al. 2014), and high light (Babla et al. 2020). This enables the operation of the GORK channels as a master switch of the cell metabolism, thus adjusting intracellular $\mathrm{K}^{+}$homeostasis to altered environmental conditions (Adem et al. 2020). Also, the $\mathrm{K}^{+}$efflux may be conducted by non-selective cation channels (Zepeda-Jazo et al. 2008). These ion channels may be key factors involved in $\mathrm{K}^{+}$leakage in the sensitive wild rice species in our study. Alternatively, $\mathrm{K}^{+}$can be actively transported into cells through HAK transporters, such as some key members (OsHAK1, OsHAK5, and OsHAK21) of this gene family in rice (Mangano et al. 2008; Chen et al. 2015; Shen et al. 2015; 


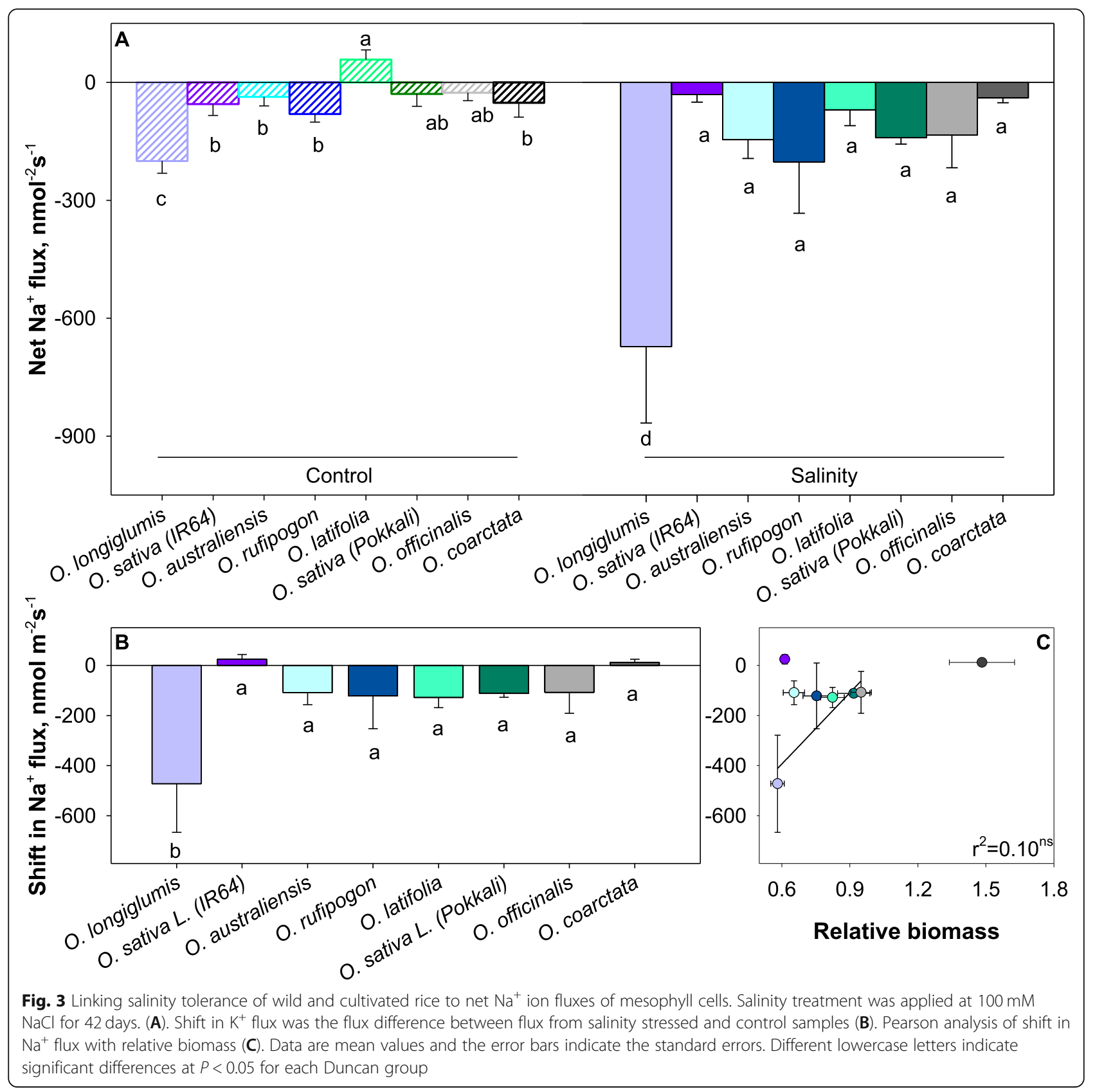

Nieves-Cordones et al. 2017; Feng et al. 2020). HAK1 and HAK5 were upregulated in both $O$. sativa and wild species. The HAK1 expression matched the results of relative biomass and $\mathrm{K}^{+}$content of four species. HAK5 expression was also highest in the most tolerant species O. coarctata and Pokkali but lowest in O. latifolia.

\section{O. coarctata is an outlier of salt tolerance among Oryza species}

The gas exchange required for photosynthesis cannot be maintained without balancing ions, organic compounds, and water contents being maintained within species- specific tissue tolerances under salinity stress (Shabala and Cuin 2008; Mishra et al. 2020; Munns et al. 2020b). In cultivated rice, photosynthetic activities are negatively correlated with the magnitude and duration of salinity stress (Yeo et al. 1985; Radanielson et al. 2018). In this study, $O$. coarctata showed a significantly greater relative biomass after salinity stress as compared to the other species (Figs. S1). In comparison to the other Oryza species, O. coarctata exhibited the highest $A$, WUE, and total chlorophyll contents in both the control and the salt-treated plants; none of these parameters was significantly affected by salinity stress (Figs. 1 and 


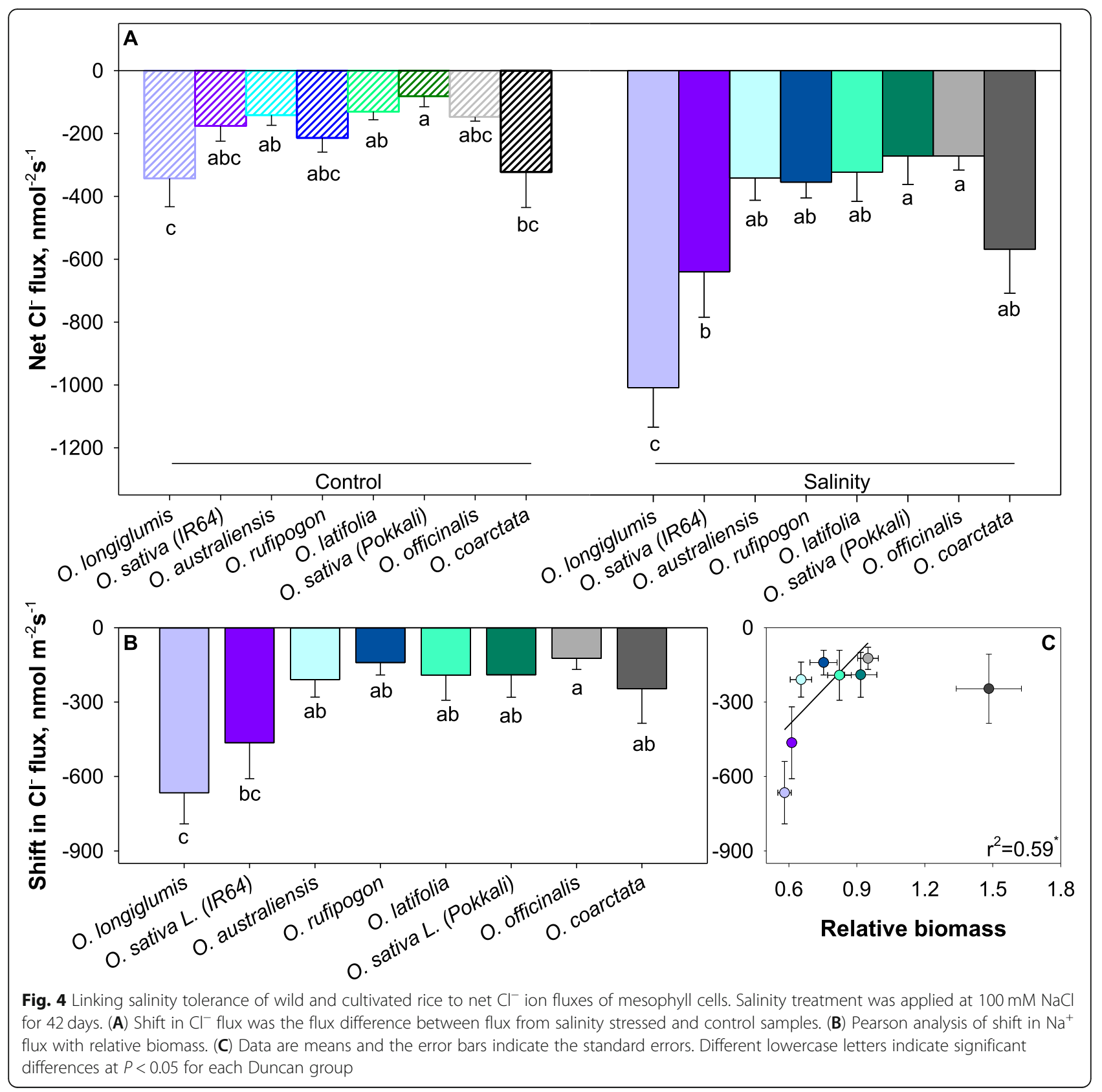

Supplementary Figs. S1), indicating remarkable adaption of photosynthetic traits to the saline condition in this species. In addition, across the six key physiological parameters that were significantly correlated with relative biomass (Figs. 2 and 4), O. coarctata was a consistent outlier compared to the studied glycophytic species, and its salinity tolerance did not show links with net $\mathrm{K}^{+}$and $\mathrm{Cl}^{-}$efflux nor to ROS production and $\mathrm{Na}^{+}$fluorescence. Thus, salinity tolerance of $O$. coarctata must be determined by other mechanisms.

Confocal imaging of $\mathrm{Na}^{+}$of $O$. coarctata revealed $\mathrm{Na}^{+}$ fluorescence in the salt glands, the vascular tissues, and in epidermal tissues is higher than that in mesophyll tissues (Fig. 6F). Therefore, most of the $\mathrm{Na}^{+}$may be transferred through the plant to the salt glands without passing through mesophyll cells, the major cell type in which photosynthesis occurs. This was validated by direct treatment of the mesophyll tissue of $O$. coarctata with the epidermis removed with $50 \mathrm{mM}$ and $100 \mathrm{mM}$ $\mathrm{NaCl}$. The directly stressed mesophyll showed obvious accumulation of $\mathrm{Na}^{+}$around or within the chloroplasts (Supplementary Figs. S2). This was not found in leaf samples with intact epidermis from plants subjected to one month of salinity treatment in hydroponic solution. Thus, O. coarctata increases $\mathrm{Na}^{+}$accumulation around the mesophyll tissue thereby maintaining photosynthesis 


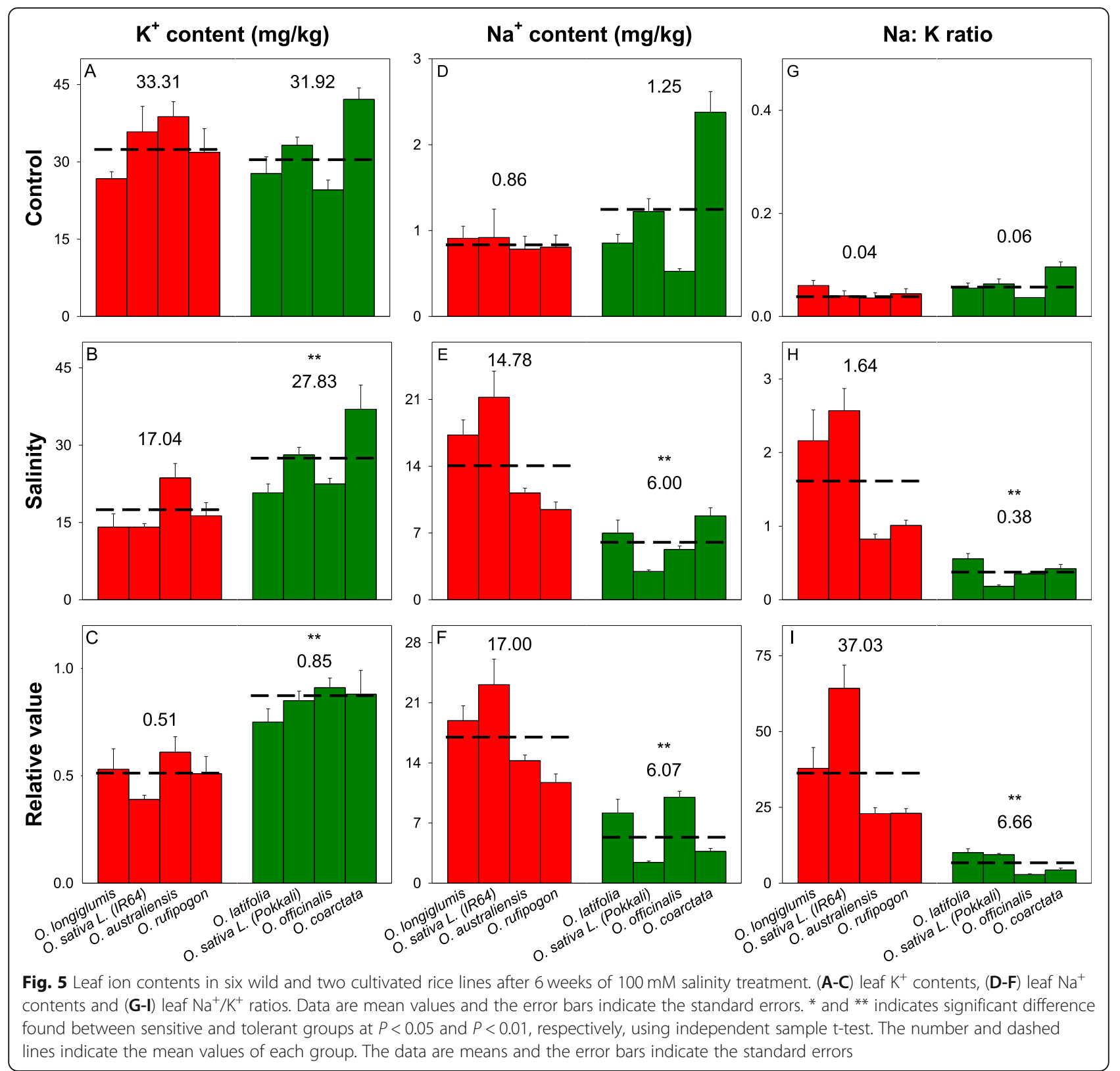

(Figs. 1); this has also been found in other plant species such as chickpea (Kotula et al. 2019; Kotula et al. 2020).

\section{Linking high photosynthetic capacity to high salt tolerance in $O$. coarctata}

There are increasing numbers of reports on the potential for the genetic engineering of $C_{4}$ photosynthesis into $C_{3}$ crops such as rice to improve their productivity and stress tolerance (Wang et al. 2017b; Ermakova et al. 2020). Evolutionarily, the transition from $C_{3}$ to $C_{4}$ photosynthesis was closely related to ambient $\mathrm{CO}_{2}$ concentration and temperature (Sage 2004; Edwards et al. 2010), which may have been a stepwise conversion of cellular biochemistry and a few key anatomical structures (Wang et al., 2017a). Three $\mathrm{C}_{3}-\mathrm{C}_{4}$ intermediate types, proto-Kranz, $\mathrm{C}_{2}-\mathrm{C}_{2}+$ photosynthesis, and $\mathrm{C}_{4}$-like photosynthesis, have been proposed based on the mesophyll cell numbers between veins, the size of bundle sheath cells, the amount and coordination of chloroplasts and mitochondria in bundle sheath cells, and Rubisco and PEPC regulation (Sage et al. 2014). In grasses, no $\mathrm{C}_{4}$ plant is reported so far in the BEP (Bambusoideae, Ehrhartoideae, Pooideae) clade; the genus, Oryza, belongs to this clade (Grass Phylogeny Working Group II, 2012). However, many members of BEP clade are reported as having $\mathrm{C}_{4}$-like leaf structure, and O. coarctata 




is currently classified in this group (Christin et al. 2013). In addition, $\mathrm{C}_{4}$ plants usually have thin leaves so that the mesophyll and bundle sheath cells can coordinate closely to assure efficiently $\mathrm{C}_{4}$ photosynthesis (Ghannoum et al. 2005). O. coarctata has developed a minor vein on top of the major vein that shortens the distance between mesophyll cells on the adaxial side and vascular system, but this feature is not found in other Oryza species (Chatterjee et al. 2016). The $\mathrm{A} / \mathrm{Ci}$ curve and $\mathrm{CO}_{2}$ compensation point indicate that the photosynthetic activities of O. coarctata are responsive to fluctuating $\mathrm{CO}_{2}$ concentration without having true $\mathrm{C}_{4}$ photosynthesis 


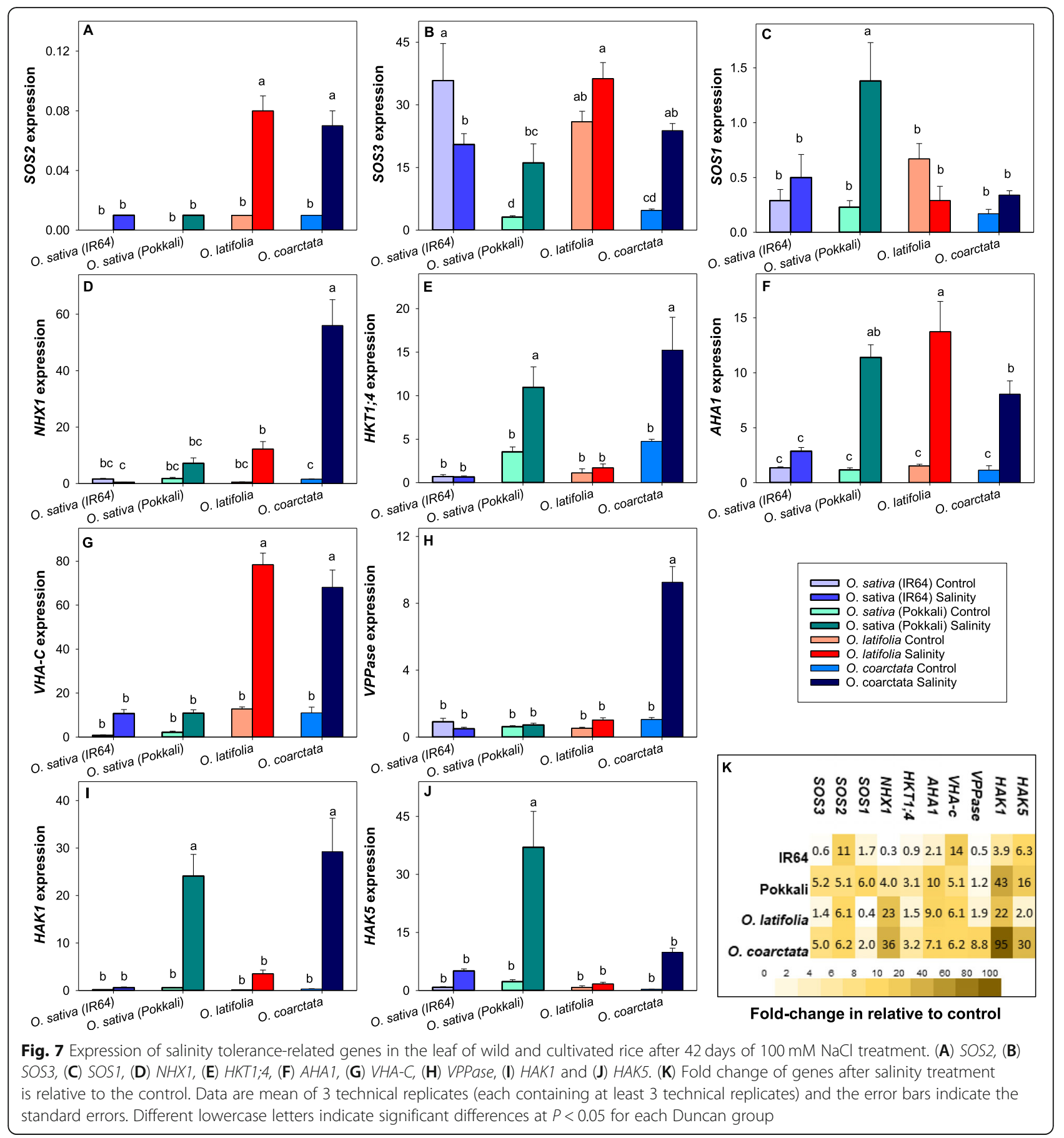

(Ku et al. 1983; Ueno et al. 2007; Schlüter et al. 2017; Monson and Jaeger 1991; Vogan and Sage 2012; Yorimitsu et al. 2019).

In $\mathrm{C}_{4}$ photosynthesis, NADP-ME, PEPC, and PPDK are responsible for oxaloacetate and phosphoenolpyruvate conversion in mesophyll cells and $\mathrm{CO}_{2}$ release in bundle sheath cells during the $\mathrm{C}_{4}$ cycle (Hibberd and Covshoff 2010). In $\mathrm{C}_{4}$ plants, Rubisco is responsible for the conversion of carbon into organic acid, and the two subunits of this enzyme, $R b c L$, and $R b c S$, are localized in chloroplasts and the nucleus, respectively (Berry et al. 2016). In this study, the expression of all $\mathrm{C}_{4}$ photosynthesis-related genes (NADPME, $P E P C, P P D K, R b c L$, and $R b c S$ ) was significantly higher in O. coarctata compared to IR64 and Pokkali. Although $O$. coarctata does not possess true $\mathrm{C}_{4}$ photosynthesis, higher gene expression, photosynthetic rates, and WUE as well as the unique morphology 


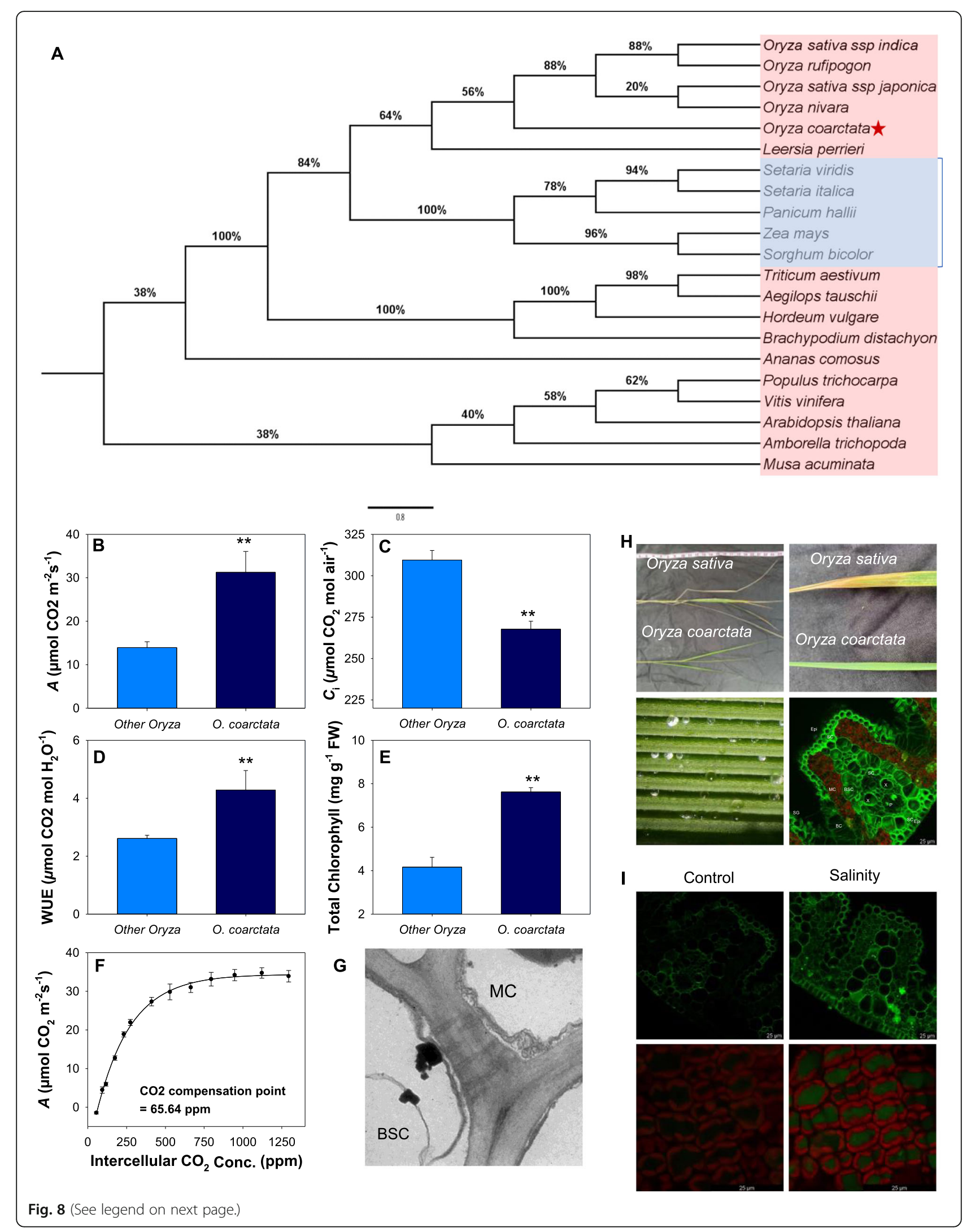


(See figure on previous page.)

Fig. 8 Phylogenetic, morphological and photosynthetic evidence of $O$. coarctata being a $C_{3}-C_{4}$ intermediate. (A) Maximum likelihood tree showing the phylogenetic relationship of PEPC, a $C_{4}$ key enzyme, in $C_{3}$ (red) and $C_{4}$ (blue) species. The percentages of trees from 1000 bootstrap replications in which the associated taxa clustered together are shown next to the branches. (B-E) Leaf gas exchange characteristics of $O$. coarctata compared to other Oryza species used in this study. (F) Photosynthesis dependence on intracellular $\mathrm{CO}_{2}$ curve fitting a $\mathrm{C}_{4}$ type photosynthesis model species. (G) Leaf ultrastructure showing the presence of plasmodesmata connecting mesophylle and bundle sheath cells. (H) Shoot and leaf morphology of $O$. sativa and $O$. coarctata, salt secretion on leaf surface of $O$. coarctata, and $\mathrm{Na}^{+}$localization from leaf cross section of $\mathrm{O}$. coarctata. Epi- epidermis, MC- mesophyll cells, BSC- bundle sheath cells, X-xylem, P- phloem, BC-bulliform cells, STsclerenchymatous thickening and SG- salt glands. (I) Na ${ }^{+}$accumulation and chlorophyll fluorescence in a leaf in response to high salinity stress in O. coarctata.. Curve was fitted with a 3-parameters exponential rise to maximum $\left[\mathrm{Net}^{\mathrm{CO}_{2}}\right.$ assimilation $=-1.191+4.628 \times\left(1-\exp \left(-4.533 \times \mathrm{CO}_{2}\right.\right.$ concentration) with a calculated $\mathrm{CO}_{2}$

will be useful to understand the salinity tolerance mechanism in this halophytic wild rice.

\section{Methods and materials}

\section{Greenhouse trial}

Six wild rice species (O. longiglumis Jansen, O. australiensis Domin, O. rufipogon Griff., O. latifolia Desv., O. officinalis Wall. ex Watt and O. coarctata Roxb.), the $O$. sativa subspecies indica cultivar, IR64, and the landrace, Pokkali, were grown in a greenhouse at Western Sydney University, Hawkesbury Campus $\left(33.62{ }^{\circ} \mathrm{S}, 150.75{ }^{\circ} \mathrm{E}\right)$. With the exception of $O$. coarctata, plants of the other species were raised from seed in sand for 14 days and then transferred to $9 \mathrm{~L}$ buckets filled with a loamy sandy soil. The remaining wild rice, O. coarctata, was prepared through vegetative propagation by separating newly emerged tillers with two leaves from parent plants. The young tillers were placed in Yoshida's medium (Yoshida et al. 1971) for 14 days and transferred to the $9 \mathrm{~L}$ buckets containing the loamy sandy soil. The times of sowing and vegetative propagation of the wild and cultivated rice species were synchronized based on previous work to ensure that the plants were in the same growth stage during the measurements. The greenhouse was maintained with controlled day/night temperatures of $29^{\circ} \mathrm{C} / 24^{\circ} \mathrm{C}$ and supplemental HPS lights with a $14 / 10 \mathrm{hday} /$ night cycle. The relative humidity was maintained at $70-80 \%$.

For each treatment and wild rice species/cultivated rice line, four replicates (4 buckets with 2 plants per bucket) were used for the different measurements. Water levels were maintained up to a height of $30 \mathrm{~mm}$ above the soil by daily watering with tap water. The initial EC of the soil was $0.25 \mathrm{dS} \mathrm{m}^{-1}$. Incremental salinity treatments using $\mathrm{NaCl}$ commenced $\sim 2$ months after sowing with increments of $2 \mathrm{dS} \mathrm{m}^{-1}$ per day until a final salinity of $10 \mathrm{dS} \mathrm{m^{-1 }}$ was reached. The final salinity treatment was maintained for six weeks before the collection of leaf samples for assessments. The EC values

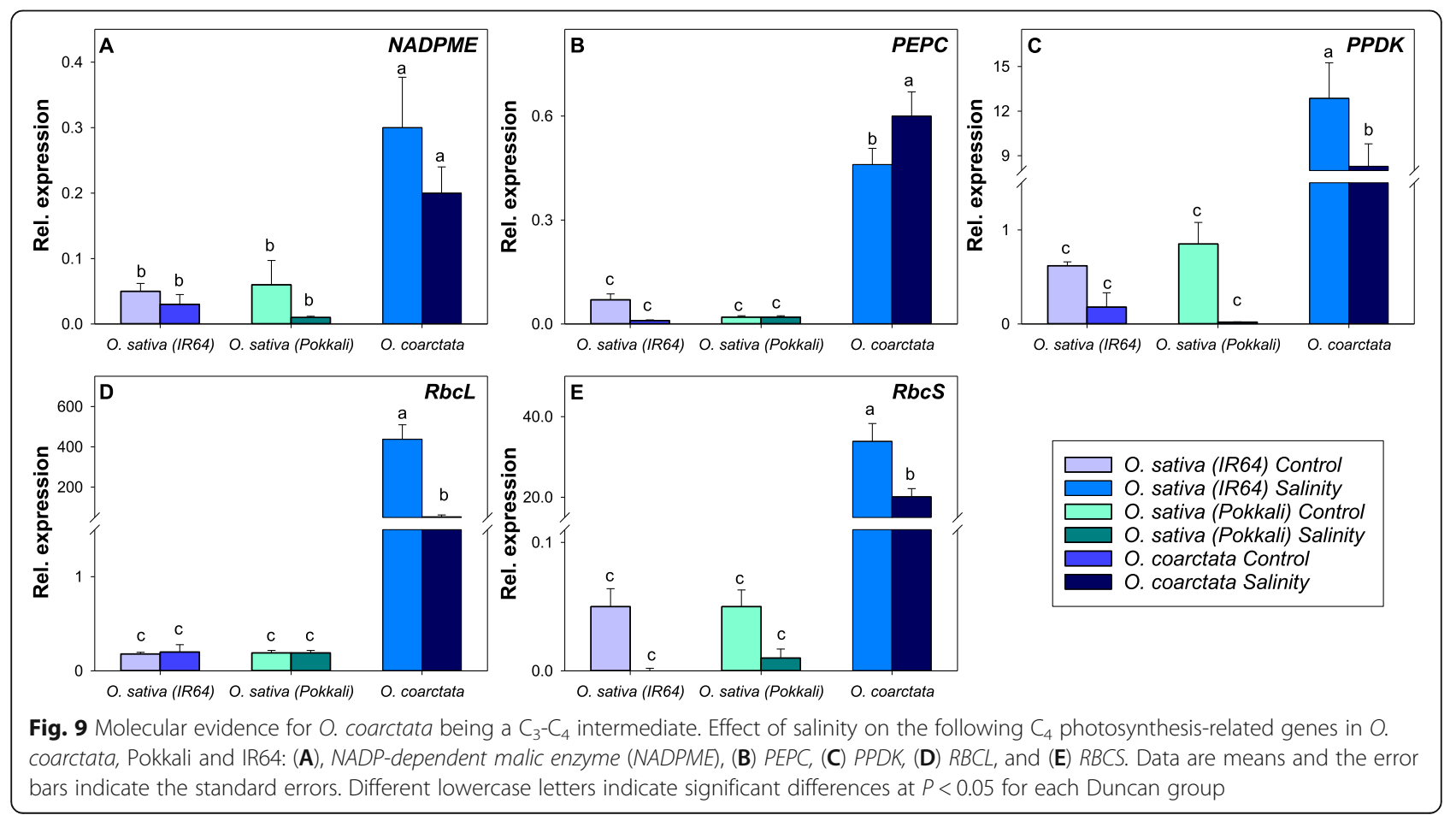


were monitored and maintained at the desired level throughout the growing season. After 42 days of salinity stress, plant height, tiller number and shoot biomass were measured. The 1st and 2nd fully expanded leaves were used for measurement of gas exchange, ion flux of mesophyll tissue, imaging of $\mathrm{Na}^{+}$and ROS in mesophyll cells, chlorophyll content, nutrient analysis, and realtime PCR.

\section{Hydroponic trials}

$O$. coarctata seedlings were prepared by vegetative propagation by separating freshly emerged tillers that had produced two leaves from their parent plants. The young tillers were placed in conical flasks containing a hydroponic solution consisting of Yoshida's medium. Each flask was covered with aluminum foil to minimize exposure of the roots to sunlight. The solution was renewed every 3 days. After 2 weeks of growth, an incremental salinity stress treatment was applied through the subsequent addition to the medium of 25, 50, and 100 $\mathrm{mM} \mathrm{NaCl}$ at 3-day intervals. After 1 month of salinity stress, $\mathrm{Na}^{+}$localization in leaf tissue was measured using confocal imaging. The epidermal layer of the leaves was removed by using scalpel. For the $2 \mathrm{~h}$ salinity treatment, the exposed mesophyll tissue was submerged in the buffer solution with 50 or $100 \mathrm{mM} \mathrm{NaCl}$.

\section{Gas exchange measurement}

In the greenhouse trial, gas exchange was measured on the first, fully-expanded leaves using a LI-6400XT infrared gas analyser (LI-COR, Lincoln, USA) following Liu et al. (2017b); three leaves were randomly selected for measurement. In each measurement, the leaf was held in the chamber for 3-5 min before the reading was taken. The chamber conditions were as follows: flow rate, $500 \mathrm{~mL} \mathrm{~min}^{-1}$, reference $\mathrm{CO}_{2} 400 \mu \mathrm{mol} \mathrm{m}{ }^{-2} \mathrm{~s}^{-1}$; block temperature, $30^{\circ} \mathrm{C}$; light fluorescence, $1000 \mu \mathrm{mol} \mathrm{m}{ }^{-2} \mathrm{~s}^{-1}$. The chamber reference humidity was maintained at $\sim 60 \%$.

For $\mathrm{A} / \mathrm{Ci}$ curve measurements, the chamber conditions were set as follows: flow rate, $500 \mathrm{~mL} \mathrm{~min}^{-1}$, block temperature, $30{ }^{\circ} \mathrm{C}$; light fluorescence, $1000 \mu \mathrm{mol} \mathrm{m}{ }^{-2}$ $\mathrm{s}^{-1}$, and reference $\mathrm{CO}_{2}, 425 \mu \mathrm{mol} \mathrm{m}{ }^{-2} \mathrm{~s}^{-1}$. Prior to the measurement, the selected leaf was held in the chamber for $20 \mathrm{~min}$. Net $\mathrm{CO}_{2}$ assimilation rate was recorded at each of the following incremental ambient $\mathrm{CO}_{2}$ concentrations: 425, 600, 800, 1000, 1250, 1500, 1750 and $2000 \mu \mathrm{mol} \mathrm{m}{ }^{-2} \mathrm{~s}^{-1}$. The readings at lower ambient $\mathrm{CO}_{2}$ concentrations of 350,250,150,100 and $50 \mu \mathrm{mol} \mathrm{m}^{-2}$ $\mathrm{s}^{-1}$ were taken after $20 \mathrm{~min}$ adaptation at $425 \mu \mathrm{mol} \mathrm{m}{ }^{-2}$ $\mathrm{s}^{-1}$ following the $2000 \mu \mathrm{mol} \mathrm{m} \mathrm{m}^{-2} \mathrm{~s}^{-1}$ treatment. The $\mathrm{CO}_{2}$ compensation point was measured from an $\mathrm{A} / \mathrm{Ci}$ curve according to Laisk (1977).

\section{Chlorophyll content}

Chlorophyll contents were determined as per Lichtenthaler and Buschmann (2001) with slight modifications. Ten milligrams of homogenised leaf samples were placed in Eppendorf tubes containing $1 \mathrm{~mL} \mathrm{80 \%} \mathrm{acetone}$ and incubated in the dark overnight. Absorbance values were obtained at 470, 649, and $664 \mathrm{~nm}$ using a spectrophotometer.

\section{Leaf $\mathrm{K}^{+}$and $\mathrm{Na}^{+}$contents}

$\mathrm{K}^{+}$and $\mathrm{Na}^{+}$contents in leaves were measured using a flame photometer (Jenway PFP7, John Morris, Australia) using a modified method based on Chen et al. (2007). The 1st and 2nd fully expanded leaves of each plant were harvested and oven-dried for 2 days. The dried leaf samples were finely ground and mixed using a Retsch Mixer Miller 400 . Each sample ( $50 \mathrm{mg})$ was digested in $4 \mathrm{~mL}$ of concentrated $\mathrm{HNO}_{3}(69 \%)$ in a boiling water bath until the sample solution was clear. The solutions were then diluted with $100 \mathrm{~mL}$ MilliQ water before measurement.

\section{Ion flux measurements}

As leaf photochemistry is ultimately linked to ionic conditions in leaf mesophyll (Pottosin and Shabala 2016; Pan et al. 2020), steady-state net $\mathrm{K}^{+}, \mathrm{Na}^{+}, \mathrm{Cl}^{-}$and $\mathrm{Ca}^{2+}$ fluxes were measured from leaf mesophyll cells of 1 st fully expanded leaves using MIFE. Microelectrode preparation and mesophyll isolation protocols were as per Shabala et al. (2012). Prior to the measurement, leaf samples $\left(20 \times 20 \mathrm{~mm}^{2}\right)$ were clamped in Perspex measuring chambers and submerged with standard MIFE solution $(0.5 \mathrm{mM} \mathrm{KCl}, 0.1 \mathrm{mM} \mathrm{CaCl} 2)$ and allowed to adapt to the new ionic environment for at least $1 \mathrm{~h}$. Steadystate ion fluxes were then measured for $\sim 5 \mathrm{~min}$ from each sample; there were 4-6 replicates for each combination of species and treatment. Net ion fluxes were calculated using MIFEFLUX software based on the ion concentration gradient recorded between two positions (see Shabala et al. (1997) for a theory and details).

\section{Confocal microscopy}

The production of $\mathrm{ROS}$ and $\mathrm{Na}^{+}$accumulation in mesophyll cells were measured using confocal microscopy according to Wang et al. (2016a). 5-(and 6-) chloromethyl$2^{\prime}, 7^{\prime}$-dichlorodihydrofluorescein diacetate, acetyl ester (CM- $\mathrm{H}_{2}$ DCFDA) was employed to monitor cellular oxidative stress, and CoroNa Green AM was employed to localize $\mathrm{Na}^{+}$distribution in leaf mesophyll tissues. The epidermal layer of the 1st fully expanded leaf was removed by using scalpel prior to incubation in a buffer

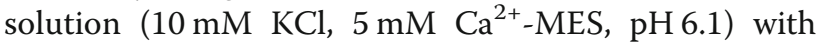
$20 \mu \mathrm{M}$ of $\mathrm{CM}-\mathrm{H}_{2}$ DCFDA or $50 \mu \mathrm{M}$ CoroNa Green for $1 \mathrm{~h}$ in the dark. ROS and $\mathrm{Na}^{+}$were measured using 
an upright laser scanning confocal microscope (Leica SP5, Germany) with $50 \times$ objective lens [laser power: $10 \%$, excitation laser: $488 \mathrm{~nm}(20 \%)$, emission range: 505-550, filter: TP488/543/633]. Chloroplasts were localized by detecting auto-fluorescence of chlorophyll at an emission range between 680 and 720 . ROS and $\mathrm{Na}^{+}$fluorescence was then quantified on a cell-by-cell basis.

\section{Quantitative real-time PCR}

Transcripts of the following $\mathrm{C}_{4}$ pathway-related genes were quantified using total RNA extracted from the first fully expanded leaf samples collected at 42 days after sowing: NADPME, (PEPC, PPDK, RBCL and $R B C S$ and salinity tolerance related genes $N H X 1$, VHA-C, VPPase, HKT1;4, SOS1, SOS2, SOS3, -ATPaseAHA1, HAK1and HAK5 (Liu et al. 2014; Wang et al. 2016b). Reverse transcription was performed as per the manufacturer's instructions (Bioline, Australia). Quantitative real-time PCR (qPCR) was performed using a Quantinova SYBR Green Kit (QIAGEN, USA) in a Rotor-Gene 3000 quantitative PCR thermoscycler (QIAGEN, USA). Relative gene expression was calculated using the comparative threshold cycle $\left(C_{t}\right) 2^{-\Delta \Delta C t}$ method (Livak et al. 2001); glyceraldehyde 3-phosphate dehydrogenase (GAPDH) and elongation factor 1-alpha $(E F 1 A)$ were used as the internal reference genes. The experiments were conducted with three biological replicates and three technical replicates. The primer pairs are listed in Supplementary Table S1.

\section{Bioinformatic analysis}

Chloroplast genome sequences from Oryza and other plant species were retrieved from public databases and were used for phylogenetic analysis of the genetic variation in cultivated and wild rice; the chloroplast genomes of five eudicot species were used as the outgroup. The sequences of PEPC, a $\mathrm{C}_{4}$ key enzyme in $\mathrm{C}_{3}$ and $\mathrm{C}_{4}$ species used in this study, were retrieved from the Michigan State University Rice Genome Annotation Project Database (http://rice.plantbiology. msu.edu/index.shtml), NCBI Protein and Nucleotide BLAST (https://blast.ncbi.nlm.nih.gov/Blast.cgi) and Ensembl Plants (http://plants.ensembl.org/index.html). These sequences were aligned using CLUSTAL W (http://www.clustal.org/clustal2/). The phylogenetic relationships among the sequences were inferred using maximum likelihood in MEGA X (Kumar et al. 2018). The percentages of trees from 1000 bootstrap replications in which the associated taxa clustered together are shown next to the branches.

\section{Data analysis}

Independent sample t-tests, ANOVA, Duncan's multiple range tests (DMRTs), Pearson's correlation was performed using IBM SPSS Statistics, Version 24 (IBM Corp. Release 2020). O. coarctata outperformed the other Oryza species in this study with respect to salinity tolerance resulting outlying data; therefore, it was excluded from the correlation analyses. The relative values of the parameters from the control and salinity treatments were calculated to evaluate the salinity sensitivity of the species/cultivars. The ranking was based on the homogenous groups identified by DMRT of the parameters listed in Supplemental Table S2. The ranking of the homogenous groups for each parameter started from 1 as the most sensitive group and increased based on the numbers of homogenous groups identified by DMRT analyses. Relative values that occurred in multiple groups were averaged (e.g., if the species was included in groups 1 and 2 it was then ranked as 1.5). The average score of all parameters was used for the final ranking.

\section{Abbreviations}

CM- $\mathrm{H}_{2}$ DCFDA: 5-(and 6-) chloromethyl-2',7'-dichlorodihydrofluorescein diacetate, acetyl ester; NADPME: NADP-dependent malic enzyme;

PEPC: phosphoenolpyruvate carboxylase; PPDK: pyruvate phosphate dikinase; RBCL: ribulose-bisphosphate carboxylase; RBCS: ribulose-1,5-bisphosphate carboxylase/oxygenase small subunit; GAPDH: glyceraldehyde 3-phosphate dehydrogenase; EF1A: elongation factor 1-alpha; HAK: high affinity potassium transporter; SOS: salt overly sensitive; NHX: sodium/hydrogen exchanger; VHA-C: V-type $\mathrm{H}^{+}$ATPase subunit $\mathrm{C}$

\section{Supplementary Information}

The online version contains supplementary material available at https://doi. org/10.1007/s44154-021-00016-z.

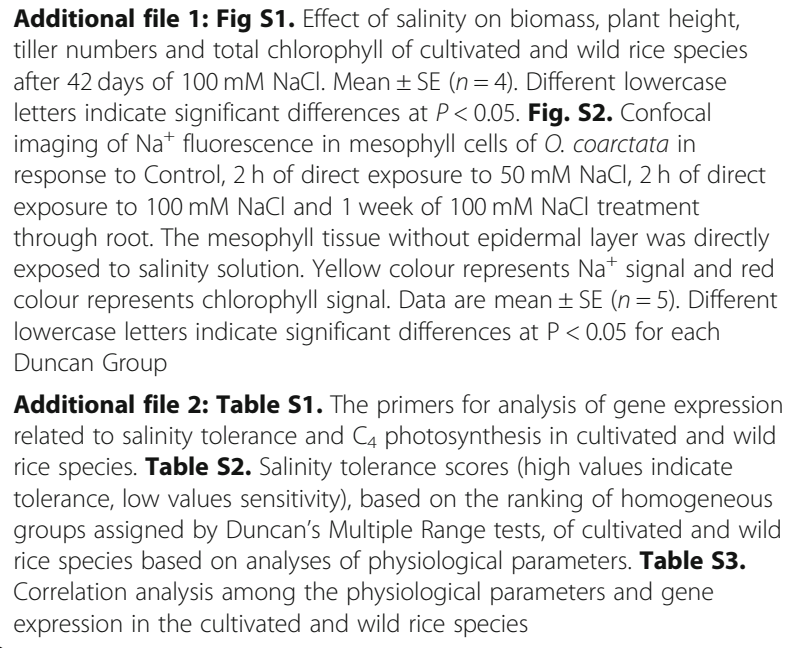

Additional file 2: Table S1. The primers for analysis of gene expression related to salinity tolerance and $C_{4}$ photosynthesis in cultivated and wild rice species. Table S2. Salinity tolerance scores (high values indicate tolerance, low values sensitivity), based on the ranking of homogeneous groups assigned by Duncan's Multiple Range tests, of cultivated and wild rice species based on analyses of physiological parameters. Table S3. Correlation analysis among the physiological parameters and gene expression in the cultivated and wild rice species

\section{Acknowledgments}

We would like to thank Dr. Rong Liu (WSU Confocal Bio-imaging Facility), Linda Westmoreland, Renee Smith, Craig Barton, Sharleen Hamersma, and Rosie Freeman for excellent technical support. The wild rice O. coarctata was obtained from the M. S. Swaminathan Research Foundation (MSSRF), India. 
Other wild rice species and cultivars were obtained from the International Rice Research Institute, Philippines respectively.

\section{Authors' contributions}

ZHC and SS designed the research. MTY, CAS, SA, GO, and RS conducted the experiments. MTY, CAS, PH and ZHC contributed to the data analysis. MTY and $\mathrm{ZHC}$ wrote the manuscript with contributions from all authors. The authors read and approved the final manuscript.

\section{Funding}

Sergey Shabala acknowledges support from the Department of Industry, Science, Energy and Resources (project AISRF48490), China National Distinguished Expert Project (WQ20174400441), grant 31961143001 for Joint Research Projects between Pakistan Science Foundation and National Natural Science Foundation, and Chinese National Natural Science Foundation (Project 31870249). Zhong-Hua Chen was supported by Australian Research Council (DE140101143; FT210100366) and by Hort Innovation Australia Projects (VG17003, LP18000). Gayatri Venkataraman acknowledges support from the Department of Biotechnology, GOI (BT/Indo-Aus/09/03/2015). Sergey Shabala also acknowledges the support provided by the National Biodiversity Authority (NBA), India Government in assisting with O. coarctata material transfer (Appl.no.1712)

\section{Availability of data and materials}

The authors declare that all data supporting the findings of this study are available within the article and its supplementary information files.

\section{Declaration}

Ethics approval and consent to participate Not applicable.

\section{Consent for publication}

Not applicable.

\section{Competing interests}

$\mathrm{SS}$ is a member of the editorial board but was not involved in the journal's review or any decisions related to this submission.

\section{Author details}

${ }^{1}$ School of Science, Western Sydney University, Penrith, NSW 2751, Australia. ${ }^{2}$ Tasmanian Institute of Agriculture, College of Science and Engineering, University of Tasmania, Hobart, Tasmania 7001, Australia. ${ }^{3}$ Plant Molecular Biology Laboratory, M. S. Swaminathan Research Foundation, III Cross Street, Taramani Institutional Area, -600113, Chennai, India. ${ }^{4}$ Hawkesbury Institute for the Environment, Western Sydney University, Penrith, NSW 2751, Australia. ${ }^{5}$ International Research Centre for Environmental Membrane Biology, Foshan University, Foshan 528000, China.

Received: 3 July 2021 Accepted: 17 November 2021

\section{Published online: 27 January 2022}

\section{References}

Adem GD, Chen G, Shabala L, Chen Z-H, Shabala S (2020) GORK channel: a master switch of plant metabolism? Trends Plant Sci 25(5):434-445. https:// doi.org/10.1016/j.tplants.2019.12.012

Babla MH, Tissue DT, Cazzonelli Cl, Chen Z-H (2020) Effect of high light on canopy-level photosynthesis and leaf mesophyll ion flux in tomato. Planta 252(5):80. https://doi.org/10.1007/s00425-020-03493-0

Bassil E, Tajima H, Liang Y-C, M-a O, Ushijima K, Nakano R, Esumi T, Coku A, Belmonte M, Blumwald E (2011) The Arabidopsis $\mathrm{Na}^{+} / \mathrm{H}^{+}$antiporters NHX1 and $\mathrm{NHX} 2$ control vacuolar $\mathrm{pH}$ and $\mathrm{K}^{+}$homeostasis to regulate growth, flower development, and reproduction. Plant Cell 23(9):3482-3497. https:// doi.org/10.1105/tpc.111.089581

Berry JO, Mure CM, Yerramsetty P (2016) Regulation of rubisco gene expression in $\mathrm{C}_{4}$ plants. Curr Opin Plant Biol 31:23-28. https://doi.org/10.1016/j.pbi.2016.03.004

Bromham L, Bennett TH (2014) Salt tolerance evolves more frequently in $C_{4}$ grass lineages. J Evol Biol 27(3):653-659. https://doi.org/10.1111/jeb.12320

Bromham L, Hua X, Cardillo M (2020) Macroevolutionary and macroecological approaches to understanding the evolution of stress tolerance in plants. Plant Cell Environ 43(12):2832-2846. https://doi.org/10.1111/pce.13857
Caperta AD, Róis AS, Teixeira G, Garcia-Caparros P, Flowers TJ (2020) Secretory structures in plants: lessons from the Plumbaginaceae on their origin, evolution and roles in stress tolerance. Plant Cell Environ 43(12):2912-2931. https://doi.org/10.1111/pce.13825

Chatterjee J, Dionora J, Elmido-Mabilangan A, Wanchana S, Thakur V, Bandyopadhyay A, Brar DS, Quick WP (2016) The evolutionary basis of naturally diverse rice leaves anatomy. PLoS ONE 11(10):e0164532. https://doi. org/10.1371/journal.pone.0164532

Chen G, Hu Q, Luo L, Yang T, Zhang S, Hu Y, Yu L, Xu G (2015) Rice potassium transporter OSHAK1 is essential for maintaining potassium-mediated growth and functions in salt tolerance over low and high potassium concentration ranges. Plant Cell Environ 38(12):2747-2765. https://doi.org/10.1111/pce.12585

Chen T, Zhu Y, Chen K, Shen C, Zhao X, Shabala S, Shabala L, Meinke H, Venkataraman G, Chen ZH (2020) Identification of new QTL for salt tolerance from rice variety Pokkali. J Agron Crop Sci 206(2):202-213. https://doi.org/1 $0.1111 /$ jac. 12387

Chen Z, Cuin TA, Zhou M, Twomey A, Naidu BP, Shabala S (2007) Compatible solute accumulation and stress-mitigating effects in barley genotypes contrasting in their salt tolerance. J Exp Bot 58(15-16):4245-4255. https://doi. org/10.1093/jxb/erm284

Chen Z, Soltis DE (2020) Evolution of environmental stress responses in plants. Plant, Cell and Environment, pp 2827-2831. https://doi.org/10.1111/pce.13922

Che-Othman MH, Millar AH, Taylor NL (2017) Connecting salt stress signalling pathways with salinity-induced changes in mitochondrial metabolic processes in $C_{3}$ plants. Plant Cell Environ 40(12):2875-2905. https://doi.org/1 $0.1111 /$ pce. 13034

Christin P-A, Osborne CP, Chatelet DS, Columbus JT, Besnard G, Hodkinson TR, Garrison LM, Vorontsova MS, Edwards EJ (2013) Anatomical enablers and the evolution of $C_{4}$ photosynthesis in grasses. Proc Natl Acad Sci 110(4):13811386. https://doi.org/10.1073/pnas.1216777110

Edwards EJ, Osborne CP, Stromberg CA, Smith SA, Consortium CG (2010) The origins of $(4$ grasslands: integrating evolutionary and ecosystem science. Science 328:587-591

Ermakova M, Danila FR, Furbank RT, von Caemmerer S (2020) On the road to $C_{4}$ rice: advances and perspectives. Plant J 101(4):940-950. https://doi.org/1 $0.1111 /$ tpj.14562

Feng X, Liu W, Qiu CW, Zeng F, Wang Y, Zhang G, Chen ZH, Wu F (2020) HvAKT2 and HVHAK1 confer drought tolerance in barley through enhanced leaf mesophyll $\mathrm{H}^{+}$homoeostasis. Plant Biotechnol J 18(8):1683-1696. https://doi. org/10.1111/pbi.13332

Flowers TJ, Galal HK, Bromham L (2010) Evolution of halophytes: multiple origins of salt tolerance in land plants. Funct Plant Biol 37(7):604-612. https://doi. org/10.1071/FP09269

Ganeshan P, Jain A, Parmar B, Rao A, Sreenu K, Mishra P, Mesapogu S, Subrahmanyam D, Ram T, Sarla N (2016) Identification of salt-tolerant rice lines among interspecific BILs developed by crossing Oryza sativa $\times$ O. rufipogon and O. sativa $\times$ O. nivara. Aust J Crop Sci 10(2):220

Ge S, Sang T, Lu B-R, Hong D-Y (2001) Phylogeny of the genus Oryza as revealed by molecular approaches. Rice Genetics IV. World Scientific, pp 89-105 https://doi.org/10.1142/9789812814296_0006

Gerona MEB, Deocampo MP, Egdane JA, Ismail AM, Dionisio-Sese ML (2019) Physiological responses of contrasting rice genotypes to salt stress at reproductive stage. Rice Sci 26(4):207-219. https://doi.org/10.1016/.rsci.2019.05.001

Ghannoum O, Evans JR, Chow WS, Andrews TJ, Conroy JP, von Caemmerer S (2005) Faster rubisco is the key to superior nitrogen-use efficiency in NADPmalic enzyme relative to NAD-malic enzyme $C_{4}$ grasses. Plant Physiol 137(2): 638-650. https://doi.org/10.1104/pp.104.054759

Grieve BD, Duckett T, Collison M, Boyd L, West J, Yin H, Arvin F, Pearson S (2019) The challenges posed by global broadacre crops in delivering smart Agri robotic solutions: a fundamental rethink is required. Glob Food Secur 23: 116-124. https://doi.org/10.1016/j.gfs.2019.04.011

Hamamoto S, Horie T, Hauser F, Deinlein U, Schroeder Jl, Uozumi N (2015) HKT transporters mediate salt stress resistance in plants: from structure and function to the field. Curr Opin Biotechnol 32:113-120. https://doi.org/10.101 6/j.copbio.2014.11.025

Hanin M, Ebel C, Ngom M, Laplaze L, Masmoudi K (2016) New insights on plant salt tolerance mechanisms and their potential use for breeding. Front Plant Sci 7:1787. https://doi.org/10.3389/fpls.2016.01787

Hatch MD (1987) $C_{4}$ photosynthesis: a unique elend of modified biochemistry, anatomy and ultrastructure. Biochimica et Biophysica Acta (BBA) - Rev Bioenerg 895(2):81-106. https://doi.org/10.1016/S0304-4173(87)80009-5 
Hibberd JM, Covshoff S (2010) The regulation of gene expression required for $\mathrm{C}_{4}$ photosynthesis. Annu Rev Plant Biol 61(1):181-207. https://doi.org/10.1146/a nnurev-arplant-042809-112238

Huertas R, Olias R, Eljakaoui Z, Gálvez FJ, Li J, De Morales PA, Belver A, RodríguezRosales MP (2012) Overexpression of SISOS2 (SICIPK24) confers salt tolerance to transgenic tomato. Plant Cell Environ 35(8):1467-1482. https://doi.org/1 0.1111/j.1365-3040.2012.02504.x

Ji H, Pardo JM, Batelli G, Van Oosten MJ, Bressan RA, Li X (2013) The salt overly sensitive (SOS) pathway: established and emerging roles. Mol Plant 6(2):275286. https://doi.org/10.1093/mp/sst017

Kavitha P, Miller A, Mathew M, Maathuis FJ (2012) Rice cultivars with differing salt tolerance contain similar cation channels in their root cells. J Exp Bot 63(8): 3289-3296. https://doi.org/10.1093/jxb/ers052

Khatun S, Flowers T (1995) Effects of salinity on seed set in rice. Plant Cell Environ 18(1):61-67. https://doi.org/10.1111/j.1365-3040.1995.tb00544.x

Kobayashi NI, Yamaji N, Yamamoto H, Okubo K, Ueno H, Costa A, Tanoi K, Matsumura H, Fujii-Kashino M, Horiuchi T (2017) OsHKT1;5 mediates $\mathrm{Na}^{+}$ exclusion in the vasculature to protect leaf blades and reproductive tissues from salt toxicity in rice. Plant J 91(4):657-670. https://doi.org/10.1111/tpj.13595

Kotula L, Clode PL, Jimenez JDLC, Colmer TD (2019) Salinity tolerance in chickpea is associated with the ability to 'exclude' Na from leaf mesophyll cells. J Exp Bot 70(18):4991-5002. https://doi.org/10.1093/jxb/erz241

Kotula L, Garcia Caparros P, Zörb C, Colmer TD, Flowers TJ (2020) Improving crop salt tolerance using transgenic approaches: an update and physiological analysis. Plant Cell Environ 43(12):2932-2956. https://doi.org/10.1111/pce.13 865

Kovach MJ, Sweeney MT, McCouch SR (2007) New insights into the history of rice domestication. Trends Genet 23(11):578-587. https://doi.org/10.1016/j. tig.2007.08.012

Kronzucker HJ, Britto DT (2011) Sodium transport in plants: a critical review. New Phytol 189(1):54-81. https://doi.org/10.1111/j.1469-8137.2010.03540.x

Ku MS, Monson RK, Littlejohn RO, Nakamoto H, Fisher DB, Edwards GE (1983) Photosynthetic characteristics of $\mathrm{C}_{3}-\mathrm{C}_{4}$ intermediate Flaveria species: I. leaf anatomy, photosynthetic responses to $\mathrm{O}_{2}$ and $\mathrm{CO}_{2}$, and activities of key enzymes in the $C_{3}$ and $C_{4}$ pathways. Plant Physiol 71(4):944-948. https://doi. org/10.1104/pp.71.4.944

Kumar V, Khare T (2015) Individual and additive effects of $\mathrm{Na}^{+}$and $\mathrm{Cl}^{-}$ions on rice under salinity stress. Arch Agron Soil Sci 61(3):381-395. https://doi.org/1 $0.1080 / 03650340.2014 .936400$

Laisk AK (1977) Kinetics of photosynthesis and photorespiration of $C_{3}$ in plants. $\mathrm{FAO}$

Lakra N, Kaur C, Anwar K, Singla-Pareek SL, Pareek A (2018) Proteomics of contrasting rice genotypes: identification of potential targets for raising crops for saline environment. Plant Cell Environ 41(5):947-969. https://doi.org/1 $0.1111 /$ pce. 12946

Lichtenthaler HK, Buschmann C (2001) Chlorophylls and carotenoids: measurement and characterization by UV-VIS spectroscopy. Curr Protoc Food Anal Chem 1(1):F4.3.1-F4.3.8. https://doi.org/10.1002/0471142913.faf0403s01

Liu J, Shabala S, Shabala L, Zhou M, Meinke H, Venkataraman G, Chen Z, Zeng F, Zhao Q (2019) Tissue-specific regulation of $\mathrm{Na}^{+}$and $\mathrm{K}^{+}$transporters explains genotypic differences in salinity stress tolerance in rice. Front Plant Sci 10: 1361. https://doi.org/10.3389/fpls.2019.01361

Liu X, Cai S, Wang G, Wang F, Dong F, Mak M, Holford P, Ji J, Salih A, Zhou M (2017a) Halophytic NHXs confer salt tolerance by altering cytosolic and vacuolar $\mathrm{K}^{+}$and $\mathrm{Na}^{+}$in Arabidopsis root cell. Plant Growth Regul 82(2):333351. https://doi.org/10.1007/s10725-017-0262-7

Liu X, Fan Y, Mak M, Babla M, Holford P, Wang F, Chen G, Scott G, Wang G, Shabala S, Zhou M, Chen Z-H (2017b) QTLs for stomatal and photosynthetic traits related to salinity tolerance in barley. BMC Genomics 18(1):9. https:// doi.org/10.1186/s12864-016-3380-0

Liu X, Mak M, Babla M, Wang F, Chen G, Veljanoski F, Wang G, Shabala S, Zhou M, Chen Z-H (2014) Linking stomatal traits and expression of slow anion channel genes HVSLAHI and HVSLAC1 with grain yield for increasing salinity tolerance in barley. Front Plant Sci 5:634. https://doi.org/10.3389/fpls.2014. 00634

Livak KJ, Schmittgen TD (2001) Analysis of relative gene expression data using real-time quantitative $P C R$ and the $2-\Delta \Delta C T$ method. Methods 25:402-408

Lutts S, Kinet JM, Bouharmont J (1996) NaCl-induced senescence in leaves of Rice (Oryza sativa L.) cultivars differing in salinity resistance. Ann Bot 78(3):389398. https://doi.org/10.1006/anbo.1996.0134
Mak M, Babla M, Xu S-C, O'Carrigan A, Liu X-H, Gong Y-M, Holford P, Chen Z-H (2014) Leaf mesophyll $\mathrm{K}^{+}, \mathrm{H}^{+}$and $\mathrm{Ca}^{2+}$ fluxes are involved in droughtinduced decrease in photosynthesis and stomatal closure in soybean. Environ Exp Bot 98:1-12. https://doi.org/10.1016/j.envexpbot.2013.10.003

Malagoli P, Britto DT, Schulze LM, Kronzucker HJ (2008) Futile $\mathrm{Na}^{+}$cycling at the root plasma membrane in rice (Oryza sativa L.): kinetics, energetics, and relationship to salinity tolerance. J Exp Bot 59(15):4109-4117. https://doi. org/10.1093/jxb/ern249

Mangano S, Silberstein S, Santa-María GE (2008) Point mutations in the barley HvHAK1 potassium transporter lead to improved $\mathrm{K}^{+}$-nutrition and enhanced resistance to salt stress. FEBS Lett 582(28):3922-3928. https://doi.org/10.1016/ j.febslet.2008.10.036

Mishra M, Wungrampha S, Kumar G, Singla-Pareek SL, Pareek A (2020) How do rice seedlings of landrace Pokkali survive in saline fields after transplantation? Physiology, biochemistry, and photosynthesis. Photosynth Res 150(1-3):117135. https://doi.org/10.1007/s11120-020-00771-6

Monson RK, Jaeger CH (1991) Photosynthetic characteristics of $C_{3}-C_{4}$ intermediate Flaveria floridana (Asteraceae) in natural habitats: evidence of advantages to $C_{3}-C_{4}$ photosynthesis at high leaf temperatures. Am J Bot 78(6):795-800. https://doi.org/10.2307/2445070

Munns R, Day DA, Fricke W, Watt M, Arsova B, Barkla BJ, Bose J, Byrt CS, Chen Z-H, Foster KJ, Gilliham M, Henderson SW, Jenkins CLD, Kronzucker HJ, Miklavcic SJ, Plett D, Roy SJ, Shabala S, Shelden MC, Soole KL, Taylor NL, Tester M, Wege S, Wegner LH, Tyerman SD (2020a) Energy costs of salt tolerance in crop plants. New Phytol 225(3):1072-1090. https://doi.org/10.1111/nph.15864

Munns R, James RA, Läuchli A (2006) Approaches to increasing the salt tolerance of wheat and other cereals. J Exp Bot 57(5):1025-1043. https://doi.org/10.1 093/jxb/erj100

Munns R, Passioura JB, Colmer TD, Byrt CS (2020b) Osmotic adjustment and energy limitations to plant growth in saline soil. New Phytol 225(3):10911096. https://doi.org/10.1111/nph.15862

Nakamura I, Murayama S, Tobita S, Bong BB, Yanagihara S, Ishimine Y, Kawamitsu $Y$ (2002) Effect of $\mathrm{NaCl}$ on the photosynthesis, water relations and free proline accumulation in the wild Oryza species. Plant Prod Sci 5(4):305-310. https://doi.org/10.1626/pps.5.305

Nemati I, Moradi F, Gholizadeh S, Esmaeili M, Bihamta M (2011) The effect of salinity stress on ions and soluble sugars distribution in leaves, leaf sheaths and roots of rice (Oryza sativa L.) seedlings. Plant Soil Environ 57(1):26-33. https://doi.org/10.17221/71/2010-PSE

Nieves-Cordones M, Mohamed S, Tanoi K, Kobayashi NI, Takagi K, Vernet A, Guiderdoni E, Périn C, Sentenac H, Véry AA (2017) Production of low-Cs ${ }^{+}$rice plants by inactivation of the $\mathrm{K}^{+}$transporter OSHAK1 with the CRISPR-Cas system. Plant J 92(1):43-56. https://doi.org/10.1111/tpj.13632

Nishizawa Y, Nakamura I, Hossain M, Akamine H, Zheng S (2015) Dry matter production and photosynthetic ability of Oryza officinalis wall ex Watt under salinity stress condition. Jpn J Crop Sci 84(1):49-55. https://doi.org/10.1626/ jcs.84.49

Oda Y, Kobayashi NI, Tanoi K, Ma JF, Itou Y, Katsuhara M, Itou T, Horie T (2018) TDNA tagging-based gain-of-function of OsHKT1;4 reinforces Na exclusion from leaves and stems but triggers $\mathrm{Na}$ toxicity in roots of rice under salt stress. Int J Mol Sci 19(1). https://doi.org/10.3390/ijms19010235

Palmgren MG, Edenbrandt AK, Vedel SE, Andersen MM, Landes X, Østerberg JT, Falhof J, Olsen LI, Christensen SB, Sandøe P (2015) Are we ready for back-tonature crop breeding? Trends Plant Sci 20(3):155-164. https://doi.org/10.101 6/j.tplants.2014.11.003

Pan T, Liu MM, Kreslavski VD, Zharmukhamedov SK, Nie CR, Yu M, Kuznetsov W, Allakhverdiev SI, Shabala S (2021) Nonstomatal limitation of photosynthesis by soil salinity. Crit Rev Environ Sci Technol 51(8):791-825

Pottosin I, Shabala S (2016) Transport across chloroplast membranes: optimizing photosynthesis for adverse environmental conditions. Mol Plant 9(3):356-370

Prusty MR, Kim S-R, Vinarao R, Entila F, Egdane J, Diaz MGQ, Jena KK (2018) Newly identified wild rice accessions conferring high salt tolerance might use a tissue tolerance mechanism in leaf. Front. Plant Sci 9(417). https://doi.org/1 $0.3389 /$ fpls.2018.00417

Queirós F, Fontes N, Silva P, Almeida D, Maeshima M, Gerós H, Fidalgo F (2009) Activity of tonoplast proton pumps and $\mathrm{Na}^{+} / \mathrm{H}^{+}$exchange in potato cell cultures is modulated by salt. J Exp Bot 60(4):1363-1374. https://doi.org/10.1 093/jxb/erp011

Radanielson AM, Angeles O, Li T, Ismail AM, Gaydon DS (2018) Describing the physiological responses of different rice genotypes to salt stress using 
sigmoid and piecewise linear functions. Field Crop Res 220:46-56. https://doi. org/10.1016/j.fcr.2017.05.001

Rajakani R, Sellamuthu G, Ishikawa T, Ahmed HA, Bharathan S, Kumari K, Shabala L, Zhou M, Chen ZH, Shabala S, Venkataraman G (2021) Reduced apoplastic barriers in tissues of shoot-proximal rhizomes of Oryza coarctata are associated with $\mathrm{Na}^{+}$sequestration. J Exp Bot (in press). https://doi.org/10.1 093/jxb/erab440

Rajakani R, Sellamuthu G, Saravanakumar V, Kannappan S, Shabala L, Meinke H, Chen Z, Zhou M, Parida A, Shabala S (2019) Microhair on the adaxial leaf surface of salt secreting halophytic Oryza coarctata Roxb. Show distinct morphotypes: isolation for molecular and functional analysis. Plant Sci 285: 248-257. https://doi.org/10.1016/j.plantsci.2019.05.004

Rodríguez-Rosales MP, Jiang X, Gálvez FJ, Aranda MN, Cubero B, Venema K (2008) Overexpression of the tomato $\mathrm{K}^{+} / \mathrm{H}^{+}$antiporter LeNHX2 confers salt tolerance by improving potassium compartmentalization. New Phytol 179(2):366-377. https://doi.org/10.1111/j.1469-8137.2008.02461.x

Sage RF (2004) The evolution of $C_{4}$ photosynthesis. New Phytol 161(2):341-370. https://doi.org/10.1111/j.1469-8137.2004.00974.x

Sage RF, Khoshravesh R, Sage TL (2014) From proto-Kranz to $C_{4}$ Kranz: building the bridge to $C_{4}$ photosynthesis. J Exp Bot 65(13):3341-3356. https://doi. org/10.1093/jxb/eru180

Schlüter U, Bräutigam A, Gowik U, Melzer M, Christin P-A, Kurz S, Mettler-Altmann T, Weber AP (2017) Photosynthesis in $C_{3}-C_{4}$ intermediate Moricandia species. J Exp Bot 68(2):191-206. https://doi.org/10.1093/jxb/erw391

Sengupta S, Majumder AL (2010) Porteresia coarctata (Roxb.) Tateoka, a wild rice: a potential model for studying salt-stress biology in rice. Plant Cell Environ 33(4):526-542. https://doi.org/10.1111/j.1365-3040.2009.02054.x

Shabala S, Cuin TA (2008) Potassium transport and plant salt tolerance. Physiol Plant 133(4):651-669. https://doi.org/10.1111/j.1399-3054.2007.01008.x

Shabala S, Cuin TA, Shabala L, Newman I (2012) Quantifying kinetics of net ion fluxes from plant tissues by non-invasive microelectrode measuring MIFE technique. Plant Salt Tolerance:119-134. https://doi.org/10.1007/978-1-61779986-0_7 Springer

Shabala S, Newman IA, Morris J (1997) Oscillations in $\mathrm{H}^{+}$and $\mathrm{Ca}^{+}$ion fluxes around the elongation region of corn roots and effects of external $\mathrm{pH}$. Plant Physiol 113(1):111-118. https://doi.org/10.1104/pp.113.1.111

Shen Y, Shen L, Shen Z, Jing W, Ge H, Zhao J, Zhang W (2015) The potassium transporter OsHAK21 functions in the maintenance of ion homeostasis and tolerance to salt stress in rice. Plant Cell Environ 38(12):2766-2779. https:// doi.org/10.1111/pce.12586

Shenton M, Kobayashi M, Terashima S, Ohyanagi H, Copetti D, HernándezHernández T, Zhang J, Ohmido N, Fujita M, Toyoda A (2020) Evolution and diversity of the wild rice Oryza officinalis complex, across continents, genome types, and ploidy levels. Genome Biol Evol 12(4):413-428. https://doi.org/10.1 093/gbe/evaa037

Solis CA, Yong MT, Vinarao R, Jena K, Holford P, Shabala L, Zhou M, Shabala S, Chen Z-H (2020) Back to the wild: on a quest for donors toward salinity tolerant rice. Front Plant Sci 11:323. https://doi.org/10.3389/fpls.2020.00323

Sweeney M, McCouch S (2007) The complex history of the domestication of rice. Ann Bot 100(5):951-957. https://doi.org/10.1093/aob/mcm128

Tsujii M, Kera K, Hamamoto S, Kuromori T, Shikanai T, Uozumi N (2019) Evidence for potassium transport activity of Arabidopsis KEA1-KEA6. Sci Rep 9(1):10040 https://doi.org/10.1038/s41598-019-46463-7

Ueno O, Bang SW, Wada Y, Kobayashi N, Kaneko R, Kaneko Y, Matsuzawa Y (2007) Inheritance of $C_{3}-C_{4}$ intermediate photosynthesis in reciprocal hybrids between Moricandia arvensis $\left(C_{3}-C_{4}\right)$ and Brassica oleracea $\left(C_{3}\right)$ that differ in their genome constitution. Plant Prod Sci 10(1):68-79. https://doi.org/10.162 6/pps.10.68

Vogan PJ, Sage RF (2012) Effects of low atmospheric $\mathrm{CO}_{2}$ and elevated temperature during growth on the gas exchange responses of $C_{3}, C_{3}-C_{4}$ intermediate, and $C_{4}$ species from three evolutionary lineages of $C_{4}$ photosynthesis. Oecologia 169(2):341-352. https://doi.org/10.1007/s00442011-2201-z

von Caemmerer S, Quick WP, Furbank RT (2012) The development of $C_{4}$ rice: current progress and future challenges. Science 336(6089):1671-1672. https:// doi.org/10.1126/science.1220177

Wang F, Chen Z-H, Liu X, Colmer TD, Shabala L, Salih A, Zhou M, Shabala S (2016a) Revealing the roles of GORK channels and NADPH oxidase in acclimation to hypoxia in Arabidopsis. J Exp Bot 68(12):3191-3204. https:// doi.org/10.1093/jxb/erw378
Wang F, Chen Z-H, Liu X, Colmer TD, Zhou M, Shabala S (2016b) Tissue-specific root ion profiling reveals essential roles of the CAX and ACA calcium transport systems in response to hypoxia in Arabidopsis. J Exp Bot 67(12): 3747-3762. https://doi.org/10.1093/jxb/erw034

Wang F, Chen Z-H, Shabala S (2017a) Hypoxia sensing in plants: on a quest for ion channels as putative oxygen sensors. Plant Cell Physiol 58(7):1126-1142. https://doi.org/10.1093/pcp/pcx079

Wang P, Khoshravesh R, Karki S, Tapia R, Balahadia CP, Bandyopadhyay A, Quick WP, Furbank R, Sage TL, Langdale JA (2017b) Re-creation of a key step in the evolutionary switch from C3 to C4 leaf anatomy. Curr Biol 27(21):3278-3287. e3276. https://doi.org/10.1016/j.cub.2017.09.040

Wang P, Vlad D, Langdale JA (2016c) Finding the genes to build $C_{4}$ rice. Curr Opin Plant Biol 31:44-50. https://doi.org/10.1016/j.pbi.2016.03.012

Wang S, Cao M, Ma X, Chen W, Zhao J, Sun C, Tan L, Liu F (2017C) Integrated RNA sequencing and QTL mapping to identify candidate genes from Oryza rufipogon associated with salt tolerance at the seedling stage. Front Plant Sci 8:1427. https://doi.org/10.3389/fpls.2017.01427

Waziri A, Kumar P, Purty R (2016) Saltol QTL and their role in salinity tolerance in rice. Austin J Biotechnol Bioeng 3(3):1067

Wu H, Zhang X, Giraldo JP, Shabala S (2018) It is not all about sodium: revealing tissue specificity and signalling roles of potassium in plant responses to salt stress. Plant Soil 431(1):1-17. https://doi.org/10.1007/s11104-018-3770-y

Yang Z, Wang C, Xue Y, Liu X, Chen S, Song C, Yang Y, Guo Y (2019) Calciumactivated 14-3-3 proteins as a molecular switch in salt stress tolerance. Nat Commun 10(1):1-12. https://doi.org/10.1038/s41467-019-09181-2

Yeo A, Caporn S, Flowers T (1985) The effect of salinity upon photosynthesis in rice (Oryza sativa L.): gas exchange by individual leaves in relation to their salt content. J Exp Bot 36(8):1240-1248. https://doi.org/10.1093/jxb/36.8.1240

Yichie Y, Brien C, Berger B, Roberts TH, Atwell BJ (2018) Salinity tolerance in Australian wild Oryza species varies widely and matches that observed in $\mathrm{O}$. sativa. Rice 11(1):66. https://doi.org/10.1186/s12284-018-0257-7

Yong M-T, Solis CA, Rabbi B, Huda S, Liu R, Zhou M, Shabala L, Venkataraman G, Shabala S, Chen Z-H (2020) Leaf mesophyll $\mathrm{K}^{+}$and $\mathrm{Cl}^{-}$fluxes and reactive oxygen species production predict rice salt tolerance at reproductive stage in greenhouse and field conditions. Plant Growth Regul 92(1):53-64. https:// doi.org/10.1007/s10725-020-00619-y

Yorimitsu Y, Kadosono A, Hatakeyama Y, Yabiku T, Ueno O (2019) Transition from $C_{3}$ to proto-Kranz to $C_{3}-C_{4}$ intermediate type in the genus Chenopodium (Chenopodiaceae). J Plant Res 132(6):839-855. https://doi.org/10.1007/s10265019-01135-5

Yoshida S, Forno DA, Cock JH (1971) Laboratory manual for physiological studies of rice. Laboratory Manual for Physiological Studies of Rice, Manila

Zepeda-Jazo I, Shabala S, Chen Z, Pottosin II (2008) $\mathrm{Na}^{+}-\mathrm{K}^{+}$transport in roots under salt stress. Plant Signal Behav 3(6):401-403. https://doi.org/10.4161/ psb.3.6.5429

Zhang JS, Xie C, Li ZY, Chen SY (1999) Expression of the plasma membrane H+ATPase gene in response to salt stress in a rice salt-tolerant mutant and its original variety. Theor Appl Genet 99(6):1006-1011. https://doi.org/10.1007/ s001220051408

Zong Y, Chen Z, Innes JB, Chen C, Wang Z, Wang H (2007) Fire and flood management of coastal swamp enabled first rice paddy cultivation in East China. Nature 449(7161):459-462. https://doi.org/10.1038/nature06135

\section{Publisher's Note}

Springer Nature remains neutral with regard to jurisdictional claims in published maps and institutional affiliations. 